PRZEGLĄD NAUK HISTORYCZNYCH 2018, R. XVII, NR 2

http://dx.doi.org/10.18778/1644-857X.17.02.12

$\underset{\text { Member since } 2018}{\mathbf{C}}|\mathbf{O}| \mathbf{P} \mid \mathbf{E}$

ARTYKUEY RECENZYJNE I RECENZJE

ZBigniew ANusiK

UNIWERSYTET ŁÓDZKi*

\title{
Kilka uwag o dziejach rodu Zborowskich w XVI wieku. Na marginesie książki Ewy Dubas-Urwanowicz
}

(Rec.: Ewa Dubas-Urwanowicz, Mężowie stanu, awanturnicy czy zdrajcy? Dzieje rodu Zborowskich w XVI wieku, Wydawnictwo DiG, Warszawa 2018, ss. 793)

W

2018 r. pojawiła się na półkach księgarskich monografia rodu Zborowskich h. Jastrzębiec pióra prof. dr hab. Ewy Dubas-Urwanowicz z Uniwersytetu w Białymstoku. Autorka tej książki należy do grona znanych i uznanych badaczy dziejów nowożytnych. Swoje zainteresowania badawcze skupia na dziejach Polski XVI i XVII w., ze szczególnym uwzględnieniem problemów prawno-ustrojowych państwa, funkcjonowania elit politycznych oraz przemian społeczno-politycznych i kulturowych w obrębie stanu szlacheckiego. Ma w swoim dorobku dwie bardzo dobrze przyjęte książki poświęcone dziejom państwa polsko-litewskiego w czasie dwóch pierwszych bezkrólewi po śmierci Zygmunta Augusta oraz w dobie panowania Stefana Batorego ${ }^{1}$.

Z cała pewnościa Ewa Dubas-Urwanowicz dysponowała więc odpowiednim przygotowaniem do tego, aby pokusić się o napisanie

* Wydział Filozoficzno-Historyczny, Instytut Historii, Katedra Historii Nowożytnej, e-mail: zanusik@uni.lodz.pl.

${ }^{1}$ Por. E. Dubas-Urwanowicz, Koronne zjazdy szlacheckie $w$ dwóch pierwszych bezkrólewiach po śmierci Zygmunta Augusta, Białystok 1998; oraz e ad e m, O nowy kształt Rzeczypospolitej. Kryzys polityczny $w$ państwie $w$ latach 15761586, Warszawa 2013. 
pracy poświęconej dziejom jednego $z$ najbardziej znanych i znaczących koronnych rodów możnowładczych w XVI w. Cel i zakres swoich badań Autorka określiła w sposób następujący: „Dom Zborowskich był najpotężniejszym rodem możnowładczym w Koronie w drugiej połowie XVI stulecia. W ciagu około siedemdziesięciu lat (dwa pokolenia Zborowskich), startując $z$ pozycji średnioszlacheckiej, doszedł w osobach swych przedstawicieli do najwyższych stanowisk w państwie. Błyskawiczna jego kariera pod koniec wieku skończyła się upadkiem. Trzecie i czwarte pokolenie szesnastowiecznych Zborowskich odnajdujemy w XVII w. ponownie w kręgach średniej szlachty. Jakie przyczyny zadecydowały o błyskotliwym awansie rodu? Co spowodowało jego gwałtowny upadek? To pierwsze pytania badawcze, nasuwające się podczas obserwacji jego dziejów. Czy były to czynniki natury politycznej, ekonomicznej, a może należy szukać przyczyn wzrostu domu Zborowskich w innej sferze badawczej, niż rozpatrywane dotąd przy okazji badania losów dużych rodzin. Rzadko w monografiach rodów i w obserwacjach rozwoju karier poszczególnych reprezentantów domu bierze się pod uwagę uwarunkowania psychologiczne czy sylwetki charakterologiczne. Może ten aspekt badawczy powinien być także wzięty pod uwagę?” (s. 11). „Pośród licznego potomstwa Marcina Zborowskiego obserwujemy jednostki barwne w wyrażaniu emocji, gwałtowne, najczęściej silne charakterologicznie. Panny Zborowskie to niewiasty dajace sobie radę $z$ problemami gospodarczymi czy wychowaniem potomstwa - nawet wówczas, gdy zostawały wdowami. W obserwacji poszczególnych członków tej rodziny nie sposób uniknąć spojrzenia na ich cechy charakterologiczne i odpowiedzieć na pytanie, jaki miały wpływ na obraz całego rodu. I w końcu - dlaczego dom Zborowskich stracił swoje znaczenie polityczne, prestiż, jedność? Które $z$ przyczyn tego zjawiska miały decydujące znaczenie, a które były drugorzędne? Pośród wszystkich wskazanych problemów stojacych przed badaczem rodu Zborowskich najważniejsza jednak [...] będzie konkluzja odpowiadajaca na pytanie zawarte w tytule pracy: kim byli bracia Zborowscy: mężami stanu, awanturnikami czy zdrajcami?” (s. 15).

Przyznać trzeba, że przygotowując się do wypełnienia postawionego przed soba zadania badawczego, Ewa Dubas-Urwanowicz wykorzystała ogromna liczbę źródeł i literatury przedmiotu. Dość powiedzieć, że kwerenda źródeł rękopiśmiennych została dokonana w 18 archiwach i bibliotekach naukowych na terenie Pol- 
ski, Litwy, Ukrainy, Rosji i Austrii. Autorka sięgnęła również do ponad 140 wydawnictw źródłowych oraz do więcej niż 400 różnego rodzaju opracowań. Słowem, podstawa źródłowa prezentowanej tu publikacji przedstawia się naprawdę imponujaco, a zamieszczona na 28 stronach wydruku bibliografia ( $z$ rejestrem wykorzystanych w pracy źródeł rękopiśmiennych) musi wywrzeć wrażenie na każdym odbiorcy. Cennym uzupełnieniem przekazu tekstowego jest także drzewo genealogiczne Zborowskich. Warto jednak zaznaczyć, że w omawianej książce nie ma jakiegokolwiek materiału ikonograficznego. Najpewniej jest to spowodowane ogromnymi rozmiarami tej pracy, liczacej ( $z$ indeksem osobowym) niemal 800 stron druku.

Konstrukcja pracy ma charakter problemowo-chronologiczny. W rozdziale pierwszym przedstawiono przodków szesnastowiecznych Zborowskich. Treść rozdziału drugiego zgodna jest $z$ jego tytułem: Koligacje. Urzędy. Wykształcenie. Majątek. W kolejnych rozdziałach Autorka omawia dzieje rodu Zborowskich na szerokim tle wydarzeń politycznych rozgrywających się w państwie polsko-litewskim w XVI w. Pewne wyobrażenie o ich zawartości dają tytuły kolejnych części omawianej pracy: Zborowscy podczas panowania Jana Olbrachta, Aleksandra i Zygmunta I Jagiellończyków; Panowanie Zygmunta Augusta. Stabilizacja pozycji rodu; Zborowscy podczas interregnum po śmierci ostatniego Jagiellona. Panowanie Henryka Walezego: oczekiwania rodu a rzeczywistość; Drugie interregnum. Ród podzielony - rozłam czy celowa taktyka; Zborowscy podczas panowania Stefana Batorego: od podziału rodu do tymczasowej jedności; Zborowscy $w$ trzecim interregnum. Walka o przetrwanie pozycji rodu; Zejście ze sceny. Losy rodu w końcu XVI stulecia. Zaproponowany przez Autorkę układ pracy ma jeden zasadniczy mankament. Informacje biograficzne dotyczace postaci poszczególnych przedstawicieli rodu Zborowskich zawarte na kartach rozdziału drugiego powielane sa bowiem niemal dosłownie w kolejnych rozdziałach, aczkolwiek zawsze w nieco innym niż pierwotnie kontekście. I jeszcze jedna uwaga. Fragmenty książki dotyczące dziejów politycznych państwa polsko-litewskiego w XVI w. sa tak rozbudowane i szczegółowe, że czasami trudno dostrzec związek między wydarzeniami opisywanymi przez Ewę Dubas-Urwanowicz a zasadniczym tematem recenzowanej monografii. Sądzić można, że nie bez wpływu na taki obrót sprawy była w tym przypadku specjalizacja naukowa Autorki - badaczki dziejów trzech pierwszych bezkró- 
lewi oraz panowania Stefana Batorego. Niemniej jednak uważam, że $z$ wielu wątków narracji obecnych w tekście omawianej tu pracy śmiało można było zrezygnować.

$Z$ punktu widzenia monografii możnowładczego rodu Zborowskich kluczowe znaczenie zdaja się mieć dwa pierwsze rozdziały. Tu bowiem Ewa Dubas-Urwanowicz pokusiła się o przedstawienie tak genealogii tej rodziny, jak i osiągniętej przez nia pozycji ekonomicznej. W obu przypadkach do ustaleń Autorki zgłosić jednak należy cały szereg zastrzeżeń. Zacznijmy może od rozdziału pierwszego, poświęconego przodkom szesnastowiecznych Zborowskich. Wiele miejsca poświęcono tu potomkom Mikołaja $z$ Łubnicy h. Jastrzębiec (zm. 1410/1411), podkomorzego łęczyckiego, rodzonego brata Wojciecha Jastrzębca (zm. 1436), arcybiskupa gnieźnieńskiego. Synami podkomorzego łęczyckiego byli Marcin (Marcisz) z Rytwian (zm. 1428), wojewoda łęczycki w latach (1425-1428), oraz Ścibor z Borysławic, Łubnicy i Rytwian (zm. 1435), wojewoda łęczycki w latach 1428-1435. Zdaniem monografistki rodu Zborowskich „Marcin [...] jest założycielem linii Jastrzębców z "Rytwian". Jego potomkowie używali nazwiska Rytwiańscy. Natomiast Ścibor rozpoczyna linię późniejszych Jastrzębców piszących się "z Borzysławic" i "ze Zborowa". Jest protoplastą szesnastowiecznych Zborowskich" (s. 29). Synem wojewody łęczyckiego Ścibora miał być - według ustaleń Autorki - starosta odolanowski Piotr ze Zborowa i Rytwian, który otrzymał Odolanów „od Kazimierza Jagiellończyka w latach siedemdziesiątych XV w., prawdopodobnie dzięki pożyczce udzielonej królowi" (s. 35). Ewa Dubas-Urwanowicz twierdzi również, że synami wspomnianego Piotra, a wnukami wojewody Ścibora byli „Marcin, Mikołaj, Andrzej, Piotr i prawdopodobnie Jan. Potwierdzeniem faktu, iż byli braćmi rodzonymi, jest ich występowanie w źródłach jako starostów odolanowskich" (s. 35).

$Z$ przykrością muszę w tym miejscu skonstatować, że $z$ całego przytoczonego tu wywodu prawdziwe jest jedynie stwierdzenie, że wojewoda łęczycki Marcin z Rytwian (zm. 1428) był przodkiem możnej rodziny Rytwiańskich h. Jastrzębiec, wygasłej w linii męskiej już na jego synach - Dziersławie (zm. 1478), kasztelanie krakowskim, i Janie (zm. 1478/1479), marszałku Królestwa i wojewodzie krakowskim. Jedyna spadkobierczynia nazwiska i majątku Rytwiańskich została w tej sytuacji wnuczka Marcina, córka wojewody krakowskiego Jana - Ewa, która około 1481 r. poślubiła Mikołaja 
Kurozwęckiego h. Poraj (zm. 1507) z czasem wojewodę lubelskiego ${ }^{2}$. Brat Marcina $z$ Rytwian (zm. 1428) - Ścibor z Borysławic, Łubnicy i Rytwian (zm. 1435) nie mógł być natomiast protoplasta rodu Zborowskich $z$ tej prostej przyczyny, że jego jedyny syn - Mikołaj zmarł bezpotomnie ${ }^{3}$. Oznacza to, że interesujaca nas rodzina nie miała nic wspólnego (poza herbem) z Jastrzębcami z Rytwian, Łubnicy i Borysławic. Również dalsza część wywodów Ewy Dubas-Urwanowicz wymaga uściślenia, korekty i sprostowania. Po pierwsze, żaden Piotr Zborowski nie był starosta odolanowskim w latach siedemdziesiątych XV w. Tenuta ta od końca lat pięćdziesiątych pozostawała bowiem w zastawie Gruszczyńskich $z$ Iwanowic h. Poraj, którzy przejęli Odolanów $z$ rąk trzymającego to starostwo od 13 lutego 1456 r. Wincentego Bieganowskiego h. Grzymała. Użytkownikiem tenuty odolanowskiej (najpewniej od 1457 r.) był początkowo Mikołaj Kośmider $z$ Iwanowic (zm. 1476), chorąży kaliski, a po jego śmierci władali Odolanowem jeszcze jego synowie - Wawrzyniec i Jan Kośmiderowie Gruszczyńscy ${ }^{4}$. Dopiero 14 grudnia 1484 r. Marcin Zborowski otrzymał konsens królewski na wykupienie starostwa odolanowskiego $z$ rąk Jana Kośmidera Gruszczyńskiego $z$ Iwanowic. Tego samego dnia król zezwolił również Zborowskiemu na wykupienie starostwa ostrzeszowskiego $z$ rąk Dobrogosta Ostroroga Lwowskiego ${ }^{5}$.

O Marcinie Zborowskim wiemy na pewno, że pochodził ze wsi Zborów w parafii Solec (powiat wiślicki), która pozostawała w rękach interesującej nas linii Jastrzębców przynajmniej od połowy lat osiemdziesiątych XIV w. Nie znamy imienia jego ojca (rzecz jasna mógł to być wspomniany przez Bartosza Paprockiego Piotr ze Zborowa, który jednak nie pełnił żadnych przypisywanych mu przez późniejszych heraldyków urzędów). W 1474 r. Kazimierz Jagiellończyk powierzył Marcinowi zadanie sformowania roty liczącej 200 jeźdźców na

${ }^{2}$ Por. W. Fałkowski, Rytwiański Jan (właściwie Jan z Rytwian) h. Jastrzębiec, [w:] Polski słownik biograficzny [dalej: PSB], t. XXXIII, Wrocław-WarszawaKraków 1991-1992, s. 588-592; K. Baczkowski, Kurozwęcki Mikołaj h. Róża (Poraj), [w:] PSB, t. XVI, Wrocław-Warszawa-Kraków 1971, s. 273-274.

3 Por. T. N ow ak, Ścibor z Borysławic, Eubnicy i Rytwian h. Jastrzębiec, [w:] PSB, t. L, Warszawa-Kraków 2014-2015, s. 441-442.

${ }^{4}$ Por. Archiwum Główne Akt Dawnych w Warszawie [dalej: AGAD], Metryka Koronna [dalej: MK] 11, k. 44, 56, 259-260; MK 12, k. 19; MK 14, k. 20; A. Szymczakowa, Szlachta sieradzka wXV wieku. Magnifici et generosi, Łódź 1998, s. 137-139, 141.

${ }^{5}$ Por. AGAD, MK 14, k. 12. 
wojnę $z$ Maciejem Korwinem ${ }^{6}$. W roku następnym pożyczył królowi 2300 florenów i uzyskał obietnicę oddania mu w użytkowanie Hrubieszowa $z$ przyległościami w przypadku, gdyby władca nie zwrócił tej sumy w określonym terminie. W tym samym czasie otrzymał też zapis sumy 1150 florenów na tenucie horodelskiej ${ }^{7}$. Funkcję rotmistrza wojsk zaciężnych pełnił też w latach 1484-1487. W uznaniu jego zasług król obiecał Zborowskiemu, że w przypadku śmierci któregoś $z$ dotychczasowych burgrabiów nada mu urząd burgrabiego zamku krakowskiego. Marcin nie doczekał jednak tego awansu, gdyż zmarł najpewniej w drugiej połowie $1489 \mathrm{r} .{ }^{8} \mathrm{Z}$ całą pewnościa nieprawdziwe jest natomiast twierdzenie Autorki, że w 1484 r. Marcin Zborowski „zastawił ponownie Odolanów i Ostrzeszów” (s. 36). Konsens na wykup tenuty ostrzeszowskiej z rąk Dobrogosta Ostroroga Lwowskiego nigdy nie został bowiem zrealizowany, a przejęcie przez Zborowskiego Odolanowa $z$ pewnością nastąpiło znacznie później. Jeszcze w 1487 r. Jan Kośmider Gruszczyński nazywany był bowiem tenutariuszem zamku odolanowskiego ${ }^{9}$.

Edward Opaliński twierdzi, że starosta odolanowski Marcin Zborowski pozostawił po sobie dwóch synów - Piotra i Andrzeja ${ }^{10}$. Ewa Dubas-Urwanowicz zaakceptowała ten pogląd. Przy okazji jednak dodatkowo zagmatwała genealogię Zborowskich. Jej zdaniem Marcin Zborowski miał bowiem zarówno braci, jak i synów noszących imiona Piotr i Andrzej. Jest to oczywista nieprawda. W rzeczywistości, u schyłku XV w. żyło jedynie dwóch przedstawicieli rodu Zborowskich noszacych te imiona. Starszym $z$ nich był bez watpienia Piotr, odnotowany w czerwcu 1494 r. jako starosta odolanowski. W maju 1499 r. uzyskał on konsens królewski na scedowanie tenu-

${ }^{6}$ Por. AGAD, MK 12, k. 201.

7 Por. AGAD, MK 12, k. 201, 203-204.

8 Żył jeszcze 30 VII 1489 r., kiedy król wystawił dokument, w którym obiecał nadanie urzędu burgrabiego krakowskiego swojemu dworzaninowi - Zygmuntowi Stoszowi. Ten ostatni miał jednak objąć ten urząd dopiero po czekajacym na wakans Marcinie Zborowskim. Por. AGAD, MK 14, k. 319; K. Bukowski, StosZ Zygmunt $z$ Kounic i Olbrachcic, [w:] PSB, t. XLIV, Warszawa-Kraków 2006-2007, s. $145-147$.

9 Por. A. Gąsiorowski, Ostroróg Dobrogost (właściwie Dobrogost z Ostroroga, także z Lwówka, Lwowski), [w:] PSB, t. XXIV, Wrocław 1979, s. 499; Biblioteka Kórnicka PAN [dalej: BK PAN], Teki Dworzaczka [dalej: TD], Grodzkie i ziemskie [dalej: GiZ], Poznań, Rezygnacje, XV wiek, część 1, 6499 (Nr. 1387), 1487.

10 Por. E. Opaliński, Rodziny wielkosenatorskie $w$ Wielkopolsce, na Kujawach i na Mazowszu za Zygmunta III. Podstawy karier, Warszawa 2007, s. 16. 
ty odolanowskiej na rzecz rodzonego brata (germano suo) Andrzeja. Zmarł bezpotomnie, najpewniej w ostatnim roku XV stulecia. Jeszcze w 1500 r. wystapił bowiem jako tenutariusz odolanowski ${ }^{11}$. Młodszy brat Piotra - Andrzej Zborowski już w 1478 r. otrzymał od króla zadanie sformowania roty liczącej 100 jezdnych. Najpóźniej w 1491 r. ożenił się z Elżbietą Szydłowiecką h. Odrowąż, córką Stanisława (zm. 1493), kasztelana radomskiego i starosty generalnego krakowskiego, oraz Zofii z Goździkowa h. Łabędź (informacji o matce Elżbiety $z$ Szydłowieckich Zborowskiej brakuje w omawianej tu pracy). Najprawdopodobniej w 1500 r. przeją od brata tenutę odolanowska, która trzymał do końca życia. W dniu 21 grudnia 1503 r. otrzymał od króla Aleksandra nominację na drą̇̇kową kasztelanię żarnowską. Zmarł w 1508 r. $^{12}$ Pozostaje w tym miejscu odpowiedzieć na pytanie, czy Piotr i Andrzej Zborowscy rzeczywiście byli synami Marcina? W moim przekonaniu jest to mało prawdopodobne. Jeśli bowiem młodszy z braci już w 1478 r. mógł zostać rotmistrzem królewskim, to należy założyć, że obaj Zborowscy przyszli na świat $\mathrm{w}$ przedziale czasowym zawartym między rokiem 1450 a 1455. Oznacza to, że Marcin musiałby urodzić się najpóźniej około roku 1425. Trudno zaś wyobrazić sobie, że mając lat z góra 60 i dysponując całkiem już sporym majątkiem, brał jeszcze udział, jako rotmistrz wojsk zaciężnych, w „wojnie księżej” na Warmii. Dużo bardziej prawdopodobne jest przypuszczenie, że należał on do pokolenia Andrzeja i Piotra Zborowskich i dowodził rotą zaciężna jako trzydziestoparolatek. Przeciwko twierdzeniu, że Marcin Zborowski był ojcem Piotra i Andrzeja, przemawia również świadectwo Bartosza Paprockiego. Ten zaś heraldyk, blisko przecież związany $z$ rodzina Zborowskich, w swoim herbarzu odnotował, że kasztelan żarnowski Andrzej był synem Piotra ${ }^{13}$. Nie wydaje się możliwe, aby Paprocki mógł pomylić imię pradziadka swoich przyjaciół i protektorów. Uważam zatem, że kolejni starostowie odolanowscy - Marcin, Piotr i Andrzej Zborowscy byli braćmi. Ich ojcem był zaś

${ }^{11}$ Por. AGAD, MK 15, k. 190; MK 17, k. 205; BK PAN, TD, GiZ, Kalisz, Inskrypcje, XVI wiek, 4719 (Nr. 5), 1500.

12 Por. AGAD, MK 14, k. 18; MK 19, k. 131; M. Lubczyński, J. Pielas, Szydłowiecki Stanisław h. Odroważ, [w:] PSB, t. XLIX, Warszawa-Kraków 20132014, s. 578-582; Urzędnicy województwa sandomierskiego XVI-XVIII wieku. Spisy, oprac. K. Chłapowski, A. Falniowska-Gradowska, red. A. Gąsiorowski, Kórnik 1993, nr 1366.

${ }^{13}$ Por. B. Paprocki, Herby rycerstwa polskiego, wyd. K.J. Turowski, Kraków 1858, s. 144. 
zapewne dziedziczacy w Zborowie i niepiastujący żadnych urzędów Piotr Zborowski, którego życiorys został, zgodnie $z$ życzeniem jego prawnuków, nieco „upiększony” przez Bartosza Paprockiego ${ }^{14}$. Dodajmy także, że nie istnieja przesłanki źródłowe, które pozwoliłyby w sposób jednoznaczny połączyć więzami pokrewieństwa $z$ tymże Piotrem i jego trzema synami, Marcinem, Piotrem i Andrzejem, kolejnymi starostami odolanowskimi, wspomnianych przez Autorkę na s. 35-36, Mikołaja oraz Jana Zborowskich ${ }^{15}$.

Tę część rozważań należy zamknąć stwierdzeniem, że potwierdzonym źródłowo protoplasta szesnastowiecznych Zborowskich był Andrzej (zm. 1508), kasztelan żarnowski. Można też wysunąć hipotezę, że jego ojcem był Piotr, a dziadkiem Marcin (Marcisz) ze Zborowa. Rzecz jasna nie mieli oni nic wspólnego $z$ możnowładczą rodziną Rytwiańskich h. Jastrzębiec.

Również przedstawiona przez Ewę Dubas-Urwanowicz w rozdziale drugim genealogia domu Zborowskich w XVI w. wymaga wprowadzenia pewnych korekt. Przypomnijmy zatem, że Andrzej Zborowski i Elżbieta $z$ Szydłowieckich mieli czworo dzieci. Synów Jana, Marcina i Piotra oraz córkę Zofię. Pokrewieństwo łączące dzieci tej pary $z$ potężnym i wielce wpływowym za panowania Zygmunta I rodem Szydłowieckich stanowiło atut nie do przecenienia. Już w kwietniu 1510 r. Jan, Marcin i Piotr Zborowscy otrzymali konsens królewski na wykupienie starostwa stopnickiego $z$ rak Stanisława Ostroroga $^{16}$. I choć transakcja ta nie doszła do skutku, stanowiła zapowiedź późniejszych awansów dwóch młodszych braci. Najstarszy Jan zginą bowiem w 1514 r. w bitwie pod Orsza. Autorka uznała, że Marcin Zborowski był najmłodszym synem Andrzeja i Elżbiety z Szydłowieckich (s. 40). Sądząc jednak na podstawie przywołanego tu wpisu do akt Metryki Koronnej, gdzie zazwyczaj wymieniano bra-

${ }^{14}$ Bartosz Paprocki uczynił Piotra Zborowskiego, syna Marcisza (co akurat może być prawda), bliskim współpracownikiem króla Kazimierza Jagiellończyka. Twierdził także, że w 1479 r. został on łowczym sandomierskim, a ożenił się z nieznaną z imienia Tęczyńską. Por. id e m, op. cit., s. 144.

15 Wbrew twierdzeniu Autorki Mikołaj Zborowski nigdy nie był starosta odolanowskim. Co prawda, B. Paprocki twierdzi, że kasztelan żarnowski Andrzej miał brata Mikołaja i przytacza nawet niektóre fakty z życiorysu tego ostatniego, ale informacje podane przez tego heraldyka, nieznającego pozostałych braci Andrzeja, wydaja się w tym przypadku mało wiarygodne. Por. B. Paprocki, op. cit., s. 144. Ponadto mam wątpliwości co do tego, czy wspomnianego tu Mikołaja Zborowskiego, uczestnika walk na Węgrzech w armii Macieja Korwina, można utożsamić (jak czyni to Autorka) z Mikołajem, tenutariuszem ropczyckim.

${ }^{16}$ Por. AGAD, MK 24, k. 258-258v. 
ci w kolejności starszeństwa, należy przypuszczać, że najmłodszym synem Andrzeja Zborowskiego był jednak Piotr. Ten ostatni został w 1515 r. krajczym koronnym po awansie swojego wuja, Mikołaja (nie Piotra, jak na s. 40) Szydłowieckiego na podskarbiostwo wielkie koronne i kasztelanię sandomierską. W 1520 r. Piotr Zborowski otrzymał urząd cześnika koronnego, z którego zrezygnował w $1527 \mathrm{r}$. na rzecz brata Marcina. W 1531 r. został kasztelanem małogoskim, a w 1548 r. kasztelanem sandomierskim. W latach 15481553 użytkował także starostwo sanockie. Wbrew twierdzeniu Ewy Dubas-Urwanowicz (s. 40) Piotr Zborowski nie był natomiast nigdy starosta sandomierskim. Zmarł bezżennie i bezpotomnie przed 8 listopada $1553 \mathrm{r}$. Trzeci $z$ braci - Marcin był prawdziwym twórca potęgi rodu Zborowskich. Swoją karierę zaczął od urzędu cześnika koronnego (1527), by przez kasztelanię (1543) i województwo kaliskie (1550), województwo poznańskie (1558), sięgnąć w 1562 r. po kasztelanię krakowską. Marcin Zborowski był także starostą odolanowskim, szydłowskim, stopnickim, będzińskim i tłumackim. Warto również dodać, że w 1564 r. podjął próbę objęcia w posiadanie bogatego starostwa samborskiego ${ }^{17}$. Krótko przed $1521 \mathrm{r}$. Marcin Zborowski ożenił się z Anną z Góry Konarską h. Awdaniec, córka Stanisława (zm. 1521) i Zofii z Brzezia Lanckorońskiej. Miał z nia bardzo liczne potomstwo. Zmarł 25 lutego 1565 r. Wdowa przeżyła męża o 10 lat. Zmarła najpewniej w 1575 r. Dodajmy także, że Zofia Zborowska (zm. 1544), jedyna córka kasztelana żarnowskiego Andrzeja, w 1511 r. poślubiła Stanisława Kurozwęckiego h. Poraj (zm. 1518), starostę wieluńskiego i krzepickiego. W 1527 r. jej drugim mężem został $z$ kolei Hieronim Szafraniec z Pieskowej Skały h. Starykoń (zm. 1554/1555), starosta chęciński. Z pierwszego małżeństwa Zofia Zborowska pozostawiła córkę Barbarę Kurozwęcka, żonę Andrzeja Górki h. Łodzia (zm. 1551), kasztelana poznańskiego

17 Marcin Zborowski pożyczył Zygmuntowi Augustowi 30 tys. złotych, która to sumę król zabezpieczył 10 VIII 1564 r. na starostwie samborskim i złożył obietnice oddania tej królewszczyzny w posesję kasztelanowi krakowskiemu i jego potomkom. Nie mogąc jednak wywiązać się z tej obietnicy, w maju 1565 r. przyznał synom i wnukom Marcina pensję w wysokości 2 tys. złotych rocznie, płacona $z$ dochodów starostwa samborskiego, która stanowić miała prowizję od kwoty 30 tys. złotych zabezpieczonej na Samborze. Por. AGAD, MK 99, k. 81v-82v, 260v-261. Ostatecznie jednak 12 VIII 1569 r. spadkobiercy kasztelana krakowskiego odprzedali zarówno pensję, jak i cała wierzytelność zabezpieczona na starostwie samborskim staroście lwowskiemu Stanisławowi Herburtowi z Fulsztyna. Por. AGAD, MK 101, k. 272-275. 
i starosty generalnego wielkopolskiego. $Z$ drugim mężem miała córkę Zofię Szafrańcównę (zm. 1566/1567), która poślubiła Mikołaja Oleśnickiego z Pińczowa h. Dębno (zm. 1566/1567).

Anna $z$ Góry Konarska urodziła Marcinowi Zborowskiemu aż 16 dzieci. Spośród nich dwie dziewczynki i jeden chłopiec zmarli we wczesnym dzieciństwie. Wieku dojrzałego dożyło siedmiu synów i sześć córek. Najstarszym synem wspomnianej pary był Marcin. Zdaniem Ewy Dubas-Urwanowicz urodził się on około 1526 r. (s. 41). Bardziej prawdopodobne wydaje się jednak, że przyszedł na świat trzy lata wcześniej. Autorka twierdzi również, że około 1545 r. Marcin Zborowski ożenił się z Urszulą Rozdrażewską $z$ Nowego Miasta. W innym jednak miejscu podaje, że ten sam Marcin w latach 1545-1546 studiował w Królewcu (s. 72). Moim zdaniem Zborowski urodził się około 1523 r., a z Rozdrażewską ożenił się (jako 24-latek) po powrocie ze studiów (Urszula została odnotowana jako jego żona w roku 1547). Dodajmy także, że wbrew przypuszczeniom Ewy Dubas-Urwanowicz (s. 41) Urszula Rozdrażewska była nie córka, ale wnuczka kasztelana rogozińskiego Hieronima Rozdrażewskiego h. Doliwa (zm. 1541). Jej rodzicami byli bowiem syn kasztelana, Piotr Rozdrażewski (nazywany też Nowomiejskim), oraz Katarzyna Mościejewska (nazywana też Wrzesieńską z racji posiadania części miasta Września) ${ }^{18}$. Marcin Zborowski w 1548 r. otrzymał urząd kasztelana krzywińskiego. Pozostał na nim do śmierci. Zmarł przed 25 marca 1562 r. Pozostawił po sobie synów Marcina i Piotra. Zdaniem Autorki pierwszy miał umrzeć w 1575 r., a drugi po roku 1569 (s. 41). Nie jest to do końca zgodne $z$ prawdą. Wiemy bowiem, że Piotr Zborowski żył jeszcze w 1579 r., gdy sprzedał dobra po ojcu podkomorzemu poznańskiemu Janowi Rozdrażewskiemu ${ }^{19}$. Zdaniem B. Paprockiego po sprzedaży dóbr wielkopolskich Piotr Zborowski osiadł w Grocholicach w województwie sandomierskim. Być może zmarł dopiero w $1587 \mathrm{r} .{ }^{20}$ Jego brat Marcin znika natomiast z akt wielkopolskich po roku 1570 (wtedy po raz ostatni pojawia

18 Por. BK PAN, TD, GiZ, Poznań, Rezygnacje, XVI wiek, 5702 (Nr. 1393), 1526; 5820 (Nr. 1393), 1527 (tu informacje o transakcjach majatkowych zwiazanych z zawarciem związku małżeńskiego przez rodziców Urszuli); GiZ, Pyzdry, Część 2, 2772, (Nr. 272), 1547 (tu Urszula Rozdrażewska odnotowana jako żona Marcina Zborowskiego).

19 Por. BK PAN, TD, GiZ, Kalisz, Rezygnacje, XVI wiek, 723 (Nr. 5), 1579.

${ }^{20}$ Por. B. Paprocki, op. cit., s. 167; AGAD, MK 134, k. 49-50 (tu wzmianka, że tenuta zabłotowska powróciła do dyspozycji króla po śmierci Piotra Zborowskiego). 
się tu jego nazwisko). Najpewniej zmarł więc właśnie w tym czasie. Potwierdzeniem tego stanu rzeczy jest wpis do ksiag grodzkich poznańskich $z$ roku 1570, gdzie Piotr Zborowski został odnotowany jako jedyny spadkobierca nieżyjącej już matki ${ }^{21}$. Obaj synowie kasztelana krzywińskiego zmarli bezżennie i bezpotomnie.

Drugim synem Marcina Zborowskiego, kasztelana krakowskiego, był Piotr. Zdaniem Autorki „musiał urodzić się najwcześniej w 1527 r." (s. 41). Nie dysponujemy żadnymi źródłami, które mogłyby potwierdzić lub też podważyć to stwierdzenie. Stosunkowo szybko Piotr Zborowski piął się po szczeblach kariery. Był kolejno dworzaninem królewskim (przed 1560) ${ }^{22}$, podkomorzym sandomierskim (1563), kasztelanem bieckim (1563), kasztelanem wojnickim (1566), wojewoda sandomierskim (1568) i wreszcie wojewodą krakowskim (1574). Ewa Dubas-Urwanowicz podaje, że użytkował także starostwa stopnickie, tłumackie, kamionackie i krakowskie (s. 42). W uzupełnieniu podajmy, że u schyłku życia (w 1580 r.) uzyskał także starostwo wojnickie ${ }^{23}$. Żona Piotra była Barbara Myszkowska h. Jastrzębiec, córka Mikołaja (zm. 1557), kasztelana wojnickiego, i Zofii Komorowskiej z Żywca h. Korczak. Dodajmy, że Piotr mógł poślubić Myszkowską najwcześniej około 1565 r., gdyż przyszła ona na świat po roku 1546, gdy pobrali się jej rodzice. Wojewoda krakowski Piotr Zborowski zmarł 13 września 1580 r. (zdaniem Autorki 22 maja 1580 r.) $)^{24}$. Pozostawił po sobie ogromne długi, które Bartosz Paprocki ocenial na 120 tys. złotych ${ }^{25}$. $Z$ małżeństwa $z$ Barbarą Myszkowską miał synów Jana i Mikołaja. Obaj przyszli na świat po 1565, a przed $1571 \mathrm{r}$. W dniu 14 marca 1571 r. wojewoda sandomierski Piotr Zborowski dokonał bowiem cesji trzech posiadanych przez siebie wówczas starostw na rzecz swoich co najwyżej kilkuletnich w tym czasie męskich potomków.

${ }^{21}$ Por. BK PAN, TD, GiZ, Poznań, Rezygnacje, XVI wiek, 10818 (Nr. 1398), 1570.

${ }^{22} \mathrm{~W}$ dniu 20 II 1560 r. Zygmunt August przyznał Piotrowi Zborowskiemu, dworzaninowi królewskiemu, pensję 300 florenów rocznie $z$ dochodów żup wielickich. Por. AGAD, MK 95, k. 317.

${ }^{23}$ Por. K. Chłapowski, Realizacja reform egzekucji dóbr 1563-1665. Sprawa zastawów królewszczyzn małopolskich, Warszawa 1984, s. 214. Informację o tym, że Piotr Zborowski był również starostą wojnickim, zamieszcza Autorka dopiero na s. 64.

${ }^{24}$ Por. Archiwum Narodowe w Krakowie [dalej: ANK], Castriensia Cracoviensia Inscriptiones [dalej: CCI] nr 122, s. 1324-1325 (tu informacja o zakończeniu przyjmowania wpisów do ksiag grodzkich w związku ze śmiercią Piotra Zborowskiego, wojewody i starosty krakowskiego, zmarłego 13 IX 1580 r.).

${ }^{25}$ Por. B. Paprocki, op. cit., s. 147. 
Jan otrzymał wówczas Tłumacz i Kamionkę Strumiłowa, a Mikołaj Stopnicę ${ }^{26}$. Ten ostatni zmarł jednak w bardzo młodym wieku w 1579 r. W roku następnym starostą stopnickim był już bowiem jego brat Jan. Co ciekawe, otrzymując tę dzierżawę, Jan Zborowski w dalszym ciagu był nieletni. Jeszcze w 1583 r. pozostawał on pod opieką swojego stryja - Jana Zborowskiego, kasztelana gnieźnieńskiego $^{27}$. Wojewodzic krakowski Jan Zborowski zmarł jako starosta stopnicki, tłumacki i kamionacki 24 marca 1586 r. Nie wydaje się, aby mógł mieć więcej niż 20 lat. Obaj synowie wojewody krakowskiego Piotra Zborowskiego zmarli więc bezżennie i bezpotomnie. Podana przez Ewę Dubas-Urwanowicz (w ślad za Kasprem Niesieckim) informacja, że wojewoda krakowski miał jeszcze nieznana $z$ imienia córkę, która wyszła za mąż za Jana Konarskiego h. Ciołek (s. 43), jest wysoce watpliwa.

Jan Zborowski był trzecim synem kasztelana krakowskiego Marcina i Anny z Góry Konarskiej. Urodził się zapewne w drugiej połowie lat trzydziestych XVI w. Starannie wykształcony (w Królewcu i Paryżu), wybrał karierę wojskowa. Był dworzaninem i rotmistrzem królewskim. W 1576 r. został kasztelanem gnieźnieńskim. Był także ostatnim w dziejach hetmanem nadwornym. Odniósł słynne zwycięstwo nad armią nieuznającego elekcji Stefana Batorego Gdańska w bitwie pod Lubieszowem (17 kwietnia 1577 r.). Trzymał starostwa odolanowskie, grudziądzkie, wołpieńskie i wendeńskie (kieskie). Był trzykrotnie żonaty. Jego pierwszą małżonką została przed 1570 r. nieznana $z$ imienia Maltzanówna, córka Joachima I, barona na Sycowie (Wartenbergu), i Bernardyny z Wallensteinów. Po śmierci Maltzanówny ożenił się w czerwcu 1572 r. z Elżbietą ks. Prońską, córka nieżyjącego już Fryderyka, wojewody kijowskiego, i Fedory Bohuszówny Bohuszewiczówny. Zgodę na małżeństwo z Elżbietą uzyskał od jej matki i jej trzeciego męża - Michała Działyńskiego, wówczas podkomorzego chełmińskiego. Warto dodać, że drugim mężem wdowy po Fryderyku ks. Prońskim był kasztelan gnieźnieński Mikołaj Trzebuchowski. Autorka twierdzi, że Zborowski zabiegał o rękę księżniczki Elżbiety ze względu na to, że się w niej od pierwszego wejrzenia zakochał. Być może jednak równie istotnym motywem tych zabiegów był duży posag panny. Wniosła ona bowiem mężowi aż 30 tys. złotych, która to sumę 17 czerwca

26 Por. AGAD, MK 108, k. 443v-447.

27 Por. BK PAN, TD, GiZ, Poznań, Inskrypcje, XVI wiek, Część 2, 9479 (Nr. 940), 1583. 
1572 r. Jan Zborowski oprawił w Warszawie na połowie wszystkich swoich dóbr ${ }^{28}$. Kasztelan gnieźnieński miał z Elżbietą ks. Prońską tylko jedną córkę - Annę (nie Elżbietę, jak twierdzi Autorka na s. 44). Jego druga żona zmarła przed 1581 r. W obliczu tej jednoznacznej i niepodlegajacej dyskusji informacji (podanej expressis verbis na s. 43) wręcz absurdalne jest stwierdzenie, że ze związku $z$ Elżbieta Prońską miał Jan Zborowski jeszcze jedną córkę - Annę, urodzona 2 marca 1584 r. Autorka wysuwa przy tej okazji przypuszczenie, że dziecko to zmarło wkrótce po urodzeniu, a być może $z$ nim zmarła Elżbieta $z$ Prońskich (s. 44). W 1581 r. Jan Zborowski ożenił się po raz trzeci. Jego wybranka została Katarzyna $z$ Konarskich h. Awdaniec, córka Jana (zm. 1599), kasztelana kaliskiego, i Anny z Opalińskich. Dodajmy, że trzecia małżonka kasztelana gnieźnieńskiego pochodziła $z$ tej samej rodziny, co jego matka i była jego nie tak znowu daleka kuzynka (pradziadek Katarzyny - kasztelan kamieński Andrzej Konarski był rodzonym bratem dziadka Jana - Stanisława $z$ Góry Konarskiego). $Z$ małżeństwa $z$ Konarska pozostawił kasztelan gnieźnieński córkę Zofię. Jan Zborowski zmarł 25 sierpnia 1603 r. w Odolanowie. Dodajmy także, że wdowa po nim wyszła za maż za Dadźboga (Teodora) Karnkowskiego, starostę bobrownickiego, a od 1614 r. wojewodę derpskiego (dorpackiego). Zmarła około $1616 \mathrm{r}$.

Starsza córka Jana Zborowskiego - Anna w 1591 r. wyszła za krajczego koronnego Piotra Opalińskiego (zm. 1600). Miała z nim synów Andrzeja i Jana Piotra oraz córki Elżbietę, Katarzynę i Zofię. Drugim mężem Anny Zborowskiej został Adam Sędziwój Czarnkowski (zm. 1627), wojewoda łęczycki i generał wielkopolski. Miała $z$ nim syna Władysława (zm. 1623) oraz córki Jadwigę, żonę Pawła Działyńskiego, wojewody pomorskiego, Annę (zm. 1629), żonę Stanisława Przyjemskiego, wojewody inowrocławskiego, a następnie marszałka nadwornego koronnego, i Dorotę, zakonnicę (imię zakonne Katarzyna) ${ }^{29}$. Autorka nie wspomina w ogóle o Władysławie i Annie, a Dorotę nazywa Katarzyną i daje jej imię zakonne Dorota. W ślad za K. Niesieckim wysuwa również przypuszczenie, że Anna ze Zborowskich Czarnkowska była matka jeszcze jednej córki - Doroty,

${ }^{28}$ Oprócz 30 tys. złotych posagu Zborowski przyznał żonie, zgodnie $z$ ówczesnym zwyczajem, również 30 tys. złotych wiana. Łącznie więc zapis na rzecz Elżbiety opiewał na 60 tys. złotych. Por. AGAD, MK 109, k. 845-847.

${ }^{29}$ Por. BK PAN, TD, GiZ, Wałcz, 757 (Nr. 79), 1628 (tu informacja o Dorocie Czarnkowskiej, w zakonie Katarzynie, córce Adama Sędziwoja Czarnkowskiego i Anny ze Zborowskich). 
żony Franciszka Dębińskiego, podkomorzego krakowskiego (s. 45). Gwoli wyjaśnienia dodajmy więc w tym miejscu, że wspomniana tu Dorota Czarnkowska, żona podkomorzego krakowskiego Franciszka Dembińskiego h. Rawicz, była w rzeczywistości córką Piotra, kasztelana śremskiego, i Anny $z$ Więcborka Zebrzydowskiej ${ }^{30}$. Młodsza córka kasztelana gnieźnieńskiego - Zofia Zborowska w 1601 r. poślubiła Jerzego ks. Radziwiłła (zm. 1613), kasztelana trockiego. Nie miała $z$ nim dzieci, które przeżyłyby ojca. Owdowiawszy, wyszła za Abrahama $z$ Lachowiec Sieniute (zm. 1632). Miała $z$ nim syna Piotra (zm. 1648) oraz córki Annę i Dorotę. Zofia ze Zborowskich Sieniucina zmarła po 1618 , a przed 1625 r.

Czwartym synem kasztelana krakowskiego Marcina Zborowskiego był Andrzej. Ewa Dubas-Urwanowicz twierdzi, że urodził się on po 1530 r. Wydaje się, że lepiej byłoby określić datę jego urodzenia na koniec lat trzydziestych XVI w. Był dworzaninem Zygmunta Augusta. W 1569 r. otrzymal urząd miecznika krakowskiego, tożsamy z miecznikostwem koronnym. W 1574 r. Henryk Walezy obdarzył go marszałkostwem nadwornym koronnym i starostwem radomskim. Zarówno urząd marszałka, jak i starostwo radomskie utracił w 1588 r. W 1590 r. dostał jednak od Zygmunta III kasztelanię biecka, która trzymał do śmierci. Wbrew twierdzeniu Autorki Andrzej Zborowski nie był natomiast nigdy starosta bieckim (s. 47). W 1574 r. Zborowski ożenił się z Barbara z Zakliczyna Jordanówna h. Trąby, córką kasztelana krakowskiego Spytka Wawrzyńca (zm. 1568) i Anny z Sieniawskich (zm. 1597) ${ }^{31}$. Była ona wdowa po Piotrze ks. Zbaraskim. Warto przy tej okazji zaznaczyć, że pierwszy mąż Barbary $z$ Jordanów Zborowskiej był wojewodzicem, a nie wojewodą trockim, jak na s. 47, 772 i 785. Ewa Dubas-Urwanowicz twierdzi, że Andrzej i Barbara $z$ Jordanów Zborowscy mieli trzech synów i trzy córki. W dalszej części swojego wywodu wymienia jednak jedynie synów - Marcina Dersława (zm. 1613), Spytka Piotra (1582-1608) oraz Andrzeja (ok. 1583-1630) (s. 47). Dodajmy też, że znane są również imiona czterech (nie trzech) córek interesującej nas pary. Były to Marianna, Helena, Krystyna i Leonora. Najstarsza z nich - Marianna była pierwszą żoną Krzysztofa de Wedel Tuczyńskiego. Zmarła bezpotomnie już w 1593 r. Trzy lata później cała szóstka jej rodzeństwa pozywała szwagra o wypłacenie procentów

30 Por. BK PAN, TD, GiZ, Poznań, Relacje, XVII wiek, 1959 (Nr. 165), 1640.

${ }^{31}$ Dnia 19 IV 1574 r. Andrzej Zborowski oprawił żonie 5000 florenów posagu na połowie swoich dóbr. Por. AGAD, MK 113, k. 42v-43v. 
od sumy posagowej (12 tys. złotych) i zwrot wniesionego mu przez Mariannę posagu ${ }^{32}$. Druga $z$ sióstr Zborowskich, Helena, została żona Jerzego Stefana Niemsty h. Jastrzębiec. Jej młodsza siostra - Krystyna najpierw wyszła za Stefana Świętopełka Bolestraszyckiego, a następnie Wojciecha Grochowskiego. Owdowiawszy po raz drugi, wstapiła do zakonu bernardynek, przyjmując imię zakonne Magdaleny. Najmłodsza $z$ kasztelanek bieckich - Leonora została zakonnica reguły św. Klary przy krakowskim kościele św. Andrzeja ${ }^{33}$. Spośród synów Andrzeja i Barbary z Jordanów Zborowskich - Marcin Dersław (zm. 1613) ożenił się z Jadwiga Padniewską h. Nowina, córką Wojciecha, kasztelana oświęcimskiego, i Jadwigi Dembińskiej h. Rawicz. Nie pozostawił po sobie potomstwa. Spytek Piotr (zm. 1608) wstapił najpierw do zakonu dominikanów, by później przenieść się do karmelitów. Nie wytrwał jednak również i w tym drugim zakonie. Zrzuciwszy habit, dokonał żywota jako człowiek świecki. Rodziny nie zdążył założyć. Tę linię domu Zborowskich kontynuować miał najmłodszy z braci - Andrzej (zm. 1630). W 1618 r. został on kasztelanem oświęcimskim. Użytkował także starostwo ujskie. Ożenił się ze Ślązaczką, Anną Trachówną z Brzezia i miał z nią pięcioro dzieci - synów Adama, Hieronima i Dersława Marcina (Marcina Dersława, Marcjana) oraz córki Leonore i Krystynę. Wszyscy synowie kasztelana oświęcimskiego zmarli bezpotomnie, przy czym jako ostatni, około 1639 r., zszedł $z$ tego świata Dersław Marcin. Dodajmy, że Ewa Dubas-Urwanowicz, znając tylko tego syna kasztelana oświęcimskiego Andrzeja, pomyliła go $z$ jego stryjem Marcinem Dersławem i przypisała mu za żonę Jadwigę Padniewską (s. 47). Spośród kasztelanek oświęcimskich Leonora poślubiła w 1617 r. Marka Antoniego Stadnickiego h. Szreniawa (zm. 1639). Zmarła bezpotomnie przed 1620 r. Jej młodsza siostra - Krystyna w 1639 r. wyszła za Jana Aleksandra Tarłę (zm. 1681), wojewodzica lubelskiego, który w przyszłości został wojewoda sandomierskim. Również ona nie miała dzieci. Zmarła około 1646 r.

Mikołaj Zborowski był piątym synem kasztelana krakowskiego Marcina i Anny z Góry Konarskiej. Bartosz Paprocki odnotował, że zmarł on 28 kwietnia w wieku 28 lat $^{34}$. Heraldyk ten nie podał jednak daty rocznej śmierci Mikołaja Zborowskiego. Autorka przyj-

${ }^{32}$ Por. BK PAN, TD, GiZ, Poznań, Relacje, XVII wiek, 2624 (Nr. 138), 1596.

${ }_{33}$ Por. M. S moleńs ki, Melsztyn. O zamku i jego panach, o kościołach i plebanach, $z$ dodatkiem o Domosławicach, Kraków 1888, s. 59.

${ }^{34}$ Por. B. Paprocki, op. cit., s. 155. 
muje, że urodził się on „prawdopodobnie w 1544 r.” (s. 48). Moim zdaniem Zborowski przyszedł na świat w drugiej połowie 1543 lub też w pierwszych miesiącach 1544 r. Konstatacja ta pozostaje w zgodzie $z$ przekazem Paprockiego. Wiemy bowiem na pewno, że piąty $z$ synów kasztelana krakowskiego Marcina zmarł wczesna wiosna 1572 r. Sama Ewa Dubas-Urwanowicz powołuje się bowiem na źródło, z którego jednoznacznie wynika, że po śmierci Mikołaja Zborowskiego Zygmunt August nadał dzierżone przez niego starostwo rumborskie Andrzejowi Sapieże. Ponieważ jednak Zborowscy nie chcieli wydać zamku i starostwa Sapiehom, wywołało to interwencję senatorów litewskich, którzy napisali list w tej sprawie do senatorów koronnych (s. 235) ${ }^{35}$. Z zupełnie niezrozumiałych dla mnie powodów, w innych miejscach swojej książki Autorka twierdzi jednak, że Mikołaj Zborowski „zmarł prawdopodobnie podczas sejmu warszawskiego w 1582 r." (s. 48) lub też że pożegnał się $z$ tym światem „na początku lat osiemdziesiątych” (s. 234). Mikołaj Zborowski był rotmistrzem królewskim. Z cesji ojca użytkował starostwo szydłowskie ${ }^{36}$. Miał także wspomniane już starostwo rumborskie. Ożenił się z Zofią z Tęczyńskich (zm. po 1588), córką Andrzeja (zm. 1561), kasztelana krakowskiego, i Anny Ożarowskiej. Warto jednak w tym miejscu zaznaczyć, że nie była ona bynajmniej stryjeczna siostrą Katarzyny Tęczyńskiej, żony Krzysztofa Radziwiłla „Pioruna” (s. 48) ${ }^{37}$.

Starosta szydłowski i rumborski pozostawił po sobie synów Krzysztofa i Piotra oraz córkę Zofię (Elżbietę). Z oczywistych względów (ich rodzice pobrali się nie wcześniej niż w 1567 lub 1568 r.) wszystkie te dzieci przyszły na świat na przełomie lat sześćdziesiatych i siedemdziesiątych XVI w. Krzysztof zmarł zapewne młodo i bezpotomnie. Jest wielce prawdopodobne, że nie żył już w roku $1593^{38}$. Jedyna córka Mikołaja Zborowskiego i Zofii Tęczyńskiej

${ }^{35}$ Por. List senatorów litewskich do senatorów koronnych, Rudniki 25 IX 1572, [w:] Akty zjazdów stanów Wielkiego Księstwa Litewskiego, t. I (Okresy bezkróle$w i)$, oprac. H. Lulewicz, Warszawa 2006, s. 31-32.

${ }^{36}$ W dniu 20 IV 1564 r. Zygmunt August potwierdził prawa Mikołaja Zborowskiego do starostwa szydłowskiego. Por. AGAD, MK 96, k. 368.

${ }^{37}$ Stryjecznym bratem Zofii z Tęczyńskich Zborowskiej był ojciec Katarzyny z Tęczyńskich Radziwiłłowej - Stanisław Tęczyński (zm. 1560), wojewoda krakowski.

38 Por. BK PAN, TD, GiZ, Kościan, Inskrypcje, 3693 (Nr. 273), 1593 (w przywołanym tu akcie, obok innych, żyjących wówczas przedstawicieli rodu Zborowskich, występuje Piotr, syn zmarłego Mikołaja, starosty szydłowskiego. Brakuje natomiast imienia Krzysztofa). 
- Zofia (Elżbieta) poślubiła Hieronima Czyżowskiego h. Topór. Miała $z$ nim synów Aleksandra, Hieronima i Krzysztofa. Niewiele wiemy o drugim synu starosty szydłowskiego i rumborskiego - Piotrze Zborowskim. Z cała pewnościa żył jeszcze w $1597 \mathrm{r} .{ }^{39} \mathrm{Nie}$ możemy jednak nawet $\mathrm{w}$ przybliżeniu określić daty jego śmierci. Według ustaleń Włodzimierza Dworzaczka żenił się dwukrotnie. Jego pierwsza żoną była nieznana $z$ imienia Maciejowska. Miał $z$ nią trójkę dzieci - Stanisława, Mikołaja i Mariannę (Marynę). Ta ostatnia została żoną Stefana Świętopełka Bolestraszyckiego. Mikołaj zmarł młodo przed 1618 r. Trzeci z synów Piotra Zborowskiego $z$ jego pierwszego małżeństwa - Stanisław, który zdaniem W. Dworzaczka zmarł, nie odegrawszy żadnej roli dziejowej, po 1618 r. (pogląd ten zaakceptowała również Autorka), to nikt inny, jak Stanisław Gabriel z Rytwian Zborowski, który w latach 1619-1639 był starosta horodelskim. W sierpniu 1634 r. otrzymał on od Katarzyny z Buczackich Ostrorogowej cesję dzierżawy Stulno w ziemi chełmskiej. W grudniu 1635 r. wojewoda bełski Rafał Leszczyński scedował natomiast miasteczko Korytnicę $z$ kilkoma przyległymi wsiami ${ }^{40}$. Stanisław Gabriel Zborowski ożenił się przed 1620 r. z Heleną Orzechowska h. Rogala. Po jej śmierci poślubił bliżej nieznaną Jadwigę $z$ Tryłęka. Zmarł bezpotomnie 9 października 1639 r.

Drugą żona Piotra Zborowskiego została Elżbieta Humieniecka ${ }^{41}$. Miał z nią dwóch kolejnych synów - Hieronima Gabriela i Piotra. Młodszy z nich - Piotr zmarł zapewne po 1620 r., gdy ukazało się dedykowane mu dzieło Piotra Ciachowskiego. Więcej wiemy natomiast o Hieronimie Gabrielu. Jego pierwszą żoną została w $1623 \mathrm{r}$. Izabela $z$ Hornostajów h. Hipocentaur, córka Hieronima i Beaty Lasocianki h. Rawicz. Była ona wdowa po Jakubie Cieszanowskim i Zygmuncie Stadnickim ${ }^{42}$. Po śmierci pierwszej żony, około 1628 r. Hieronim Gabriel Zborowski poślubił Helenę Brodecką. W 1643 r. kupił od Krystyny ze Zborowskich Tarłowej włość iwnicką w woje-

39 Por. ANK, CCI nr 161, s. 631-633.

40 Por. AGAD, MK 181, k. 28v-29v (tu Katarzyna z Buczacza Ostrorogowa nazwana mylnie Anna z Podhajec Ostrorogowa), 137v-138.

${ }^{41}$ Autorka, pisząc o drugim małżeństwie Piotra Zborowskiego, nazywa go Mikołajem i daje mu za żonę Elżbietę Humiecką. Jej zdaniem synami tej pary byli Hieronim (Gabriel) i Gabriel Stanisław, w latach 1619-1639 starosta horodelski.

${ }^{42}$ Por. W. Łoziński, Prawem i lewem. Obyczaje na Czerwonej Rusi w pierwszej połowie XVII wieku, t. II (Wojny prywatne), wyd. 5, Kraków 1957, s. 372-374, 380; W. Dworzaczek, Genealogia, t. II (Tablice), Warszawa 1959, tabl. 133. 
wództwie kijowskim. Zmarł po $1648 \mathrm{r} \cdot{ }^{43} \mathrm{Z}$ pierwszego małżeństwa Hieronim Gabriel Zborowski pozostawił syna Jana, ożenionego $z$ Helena Taszycka h. Strzemię. Zmarł on bezpotomnie w latach osiemdziesiatych XVII w. Synem Hieronima Gabriela $z$ drugiego małżeństwa był natomiast Aleksander Zborowski. Jan i Aleksander Zborowscy byli ostatnimi męskimi potomkami kasztelana krakowskiego Marcina i Anny z Góry Konarskiej. Dodajmy jednak, że młodszy z braci - Aleksander Zborowski poślubił Teresę Kochanowską h. Ślepowron i miał $z$ nią córke - Helenę (zm. 1728). Na tej ostatniej, żonie chorażego krakowskiego Stanisława Łętowskiego h. Ogończyk (zm. 1735), wygasła rodzina $z$ Rytwian Zborowskich.

Szóstym synem kasztelana krakowskiego Marcina był sławny i osławiony Samuel Zborowski. Ewa Dubas-Urwanowicz uważa, że musiał się on urodzić około 1550 r. (s. 49). Moim zdaniem jest to niemożliwe ze względu na wiek jego matki. Autorka przyjęła, że Anna $z$ Góry Konarska urodziła się w 1499 r. $Z$ pewnością nie mogła zatem rodzić dzieci, mając więcej niż 50 lat. Nawet jeśli przesuniemy datę jej urodzin na rok 1502 (co wydaje się bardziej prawdopodobne), to i tak ostatni jej potomek mógł przyjść na świat nie później niż w 1547 r. W moim przekonaniu Samuel Zborowski urodził się w $1545 \mathrm{r}$. Kiedy rozpoczynał swoje studia w Wittenberdze w 1557 r. (s. 73), nie mógł mieć bowiem mniej niż 12 lat. Jego żoną została Zofia Jordanówna, córka kasztelana krakowskiego Spytka Wawrzyńca i Anny z Sieniawskich, rodzona siostra Barbary, żony starszego brata Samuela - Andrzeja. Samuel Zborowski, w 1574 r. skazany na banicję za zabójstwo kasztelana przemyskiego Stanisława Wapowskiego, został ścięty w Krakowie 26 maja 1584 r. Zdaniem Ewy Dubas-Urwanowicz Zborowski miał synów: „Samuela i Aleksandra, i córki: Annę i Zofię. Samuel Zborowski syn Samuela, zmarł przed 1574 r. Prawdopodobnie we wczesnym dzieciństwie zmarła też jego córka Zofia" (s. 49). Nieprawdą jest, że Samuel Zborowski junior zmarł przed $1574 \mathrm{r}$. Żył on bowiem jeszcze w sierpniu 1597 r., kiedy uczestniczył z bratem i siostrami w podziale spadku po Spytku Wawrzyńcu i Annie $z$ Sieniawskich Jordanach ${ }^{44}$. Młodsza córka Samuela Zborowskiego miała zaś na imię nie Zofia, ale Elżbieta. W 1595 r. jej mężem został węgierski wielmoża Zygmunt Balassa de Gyarmath, pan na Bystrzycy i Modrym Kamieniu.

${ }^{43}$ Por. H. Litwi in, Napływ szlachty polskiej na Ukraine 1569-1648, Warszawa 2000, s. 180.

${ }^{44}$ Por. ANK, CCI nr 161, s. 963. 
Również i ona została odnotowana $z$ małżonkiem $\mathrm{w}$ akcie podziału spadku po Jordanach ${ }^{45}$. Starszy syn Samuela - Aleksander (zm. 1637) był zasłużonym rotmistrzem królewskim. Otrzymał od Zygmunta III starostwo międzyrzeckie, które w roku 1617 odprzedał za 60 tys. złotych swojemu krewniakowi (był on prawnukiem kasztelana krakowskiego Marcina Zborowskiego), Jerzemu Ostrorogowi Lwowskiemu ${ }^{46}$. Aleksander Zborowski ożenił się z Magdaleną z Fredrów h. Bończa, córką Jana, kasztelana przemyskiego, i Anny ze Stadnickich. Miał z nią córki Annę i Konstancję oraz syna Adama (zm. 1652), który wstąpił do zakonu jezuitów. Starsza córka Aleksandra - Anna Zborowska w 1634 r. wyszła za Aleksandra Korycińskiego h. Topór, $z$ czasem wojewodę rawskiego. Miała $z$ nim syna Stanisława oraz córki Teofilę, Konstancję, Annę i Aleksandrę. Młodsza córka Aleksandra Zborowskiego - Konstancja w 1637 r. poślubiła Rafała Grochowskiego h. Junosza, z czasem kasztelana lwowskiego. Grochowscy mieli synów Stanisława, Aleksandra i Jerzego oraz córkę Annę. Starsza córka banity Samuela - Anna Zborowska została żoną Ludwika Mortęskiego (zm. 1615), który zakończył swoją karierę senatorską na urzędzie wojewody chełmińskiego. W uzupełnieniu wywodów Autorki dodać wypada, że Ludwik i Anna ze Zborowskich Mortęscy mieli dwie córki - Zofię Magdalenę i Annę. Ich matka, Anna ze Zborowa zmarła przed rokiem $1602^{47}$.

Krzysztof Zborowski był siódmym, najmłodszym synem kasztelana krakowskiego Marcina i Anny z Góry Konarskiej. Z oczywistych powodów nie mógł się on urodzić ani w 1550 r., ani też później (s. 50). W moim przekonaniu przyszedł on na świat w roku 1547. W 1574 r. otrzymał urząd podczaszego koronnego. Już jednak w 1576 r. podczaszym koronnym tytułował się Andrzej Zebrzydowski. W 1585 r. wyrokiem sądu sejmowego Krzysztof Zborowski został skazany na infamię i konfiskatę dóbr. W tym czasie pozostawał już w służbie cesarza Rudolfa II, w której wytrwał do końca życia. Ożenił się $z$ nieznana $z$ imienia i nazwiska bogatą wdową po jakimś morawskim szlachcicu (być może pochodził on, jak przypuszcza Autorka, $z$ rodziny Cavagni vel Cavan de Burgeri). Krzysztof Zborowski zmarł bezpotomnie w 1593 r.

Zofia Zborowska była najstarszą córka i najstarszym dzieckiem kasztelana krakowskiego Marcina i Anny z Góry Konarskiej. Uro-

\footnotetext{
45 Ibidem.

46 Por. BK PAN, TD, GiZ, Wschowa, Część 2, 1559 (Nr. 31), 1617.

47 Por. BK PAN, TD, GiZ, Nakło, Część 1, 324 (Nr. 165 Inscr.), 1602.
} 
dziła się zapewne w 1521 r. W 1537 r. była już bowiem żona Wojciecha Ostroroga Lwowskiego ${ }^{48}, z$ czasem kasztelana santockiego, który zmarł w 1557 r. Miała $z$ nim synów Krzysztofa, zmarłego około 1572 r., Marcina (zm. 1590/1591), kasztelana kamieńskiego, i Piotra, który zmarł zapewne przed 1570 r. Córkami Wojciecha i Zofii były natomiast Barbara (zm. po 1604), która 17 kwietnia 1580 r. poślubiła we Lwówku Jana Opalińskiego, kasztelana rogozińskiego, oraz Anna, wspomniana w 1570 r., która została zakonnica. Wnuk Zofii ze Zborowskich - Jerzy Ostroróg Lwowski (syn Marcina) był ostatnim męskim potomkiem tej gałęzi Ostrorogów, która dziedziczyła na Lwówku. Zmarł bezpotomnie w 1623 r. jako starosta międzyrzecki. Ewa Dubas Urwanowicz podaje, że Zofia ze Zborowskich Ostrorogowa Lwowska zmarła po 1563 r. (s. 53). Jest to informacja o tyle nieścisła, że wiemy na pewno, że kasztelanowa santocka żyła jeszcze w 1572 r. ${ }^{49}$ Druga córką kasztelana krakowskiego Marcina i Anny $z$ Góry Konarskiej była Anna Zborowska. Niestety, niemal wszystkie informacje na jej temat podane przez Autorkę wymagają skorygowania. Otóż pierwszym mężem Anny był nie Zygmunt, ale Jan (Johann) Kurzbach baron na Miliczu. Z Kurzbachem miała Anna Zborowska syna Zygmunta (1547-1579) oraz być może córkę Annę. Owdowiała 18 maja 1549 r. ${ }^{50} \mathrm{~W} 1554$ r. Anna ze Zborowskich Kurzbachowa wyszła ponownie za maż za Jana Borka Gostyńskiego h. Gryzima ${ }^{51}$. Jego ojciec nie nazywał się jednak Mikołaj, ale Jan i był postacią dość znaczaca na wielkopolskiej scenie politycznej52. Dodajmy także, że drugi mąż Anny Zborowskiej miał braci Mikołaja i Krzysztofa oraz siostrę Annę, która była żoną Jana Opalińskiego, kasztelana santockiego, i matką Jana, kasztelana rogozińskiego, męża wspomnianej Barbary z Ostrorogów Lwowskich. Anna ze

48 W 1537 r. Wojciech oprawił posag Zofii wynoszacy 3000 złotych na połowie dóbr, które miał otrzymać ze spadku po rodzicach. Por. BK PAN, TD, GiZ, Poznań, Rezygnacje, XVI wiek, 261 (Nr. 1394), 1537.

49 Por. BK PAN, GiZ, Konin, 3930 (Nr.16 i Rel. Kon. 16), 1572.

${ }^{50}$ Por. Z. Anu sik, Kim była hrabianka Dorota von Helfenstein? Przyczynek do genealogii rodzin Kurzbachów i Helfensteinów w XV wieku, „Przegląd Nauk Historycznych" 2017, R. XVI, nr 2, s. 229.

51 W tym właśnie roku Jan Borek Gostyński oprawił Annie 3000 złotych posagu na połowie swoich dóbr. Por. BK PAN, TD, Poznań, Rezygnacje, XVI wiek, 7782 (Nr. 1396), 1554.

${ }^{52}$ Warto zwrócić uwage na to, że na s. 99 omawianej tu pracy znajduje się następująca, jakże trafna w tym przypadku, konstatacja Autorki: „Jan Gostyński, mąż Anny, był więc prawdopodobnie synem Jana, owego parlamentarzysty $z$ lat dwudziestych XVI stulecia”. 
Zborowskich po raz drugi została wdowa około 1558 r. Z drugim mężem miała synów Marcina i Jana Borków Gostyńskich oraz córkę Zofię, która przed 1578 r. poślubiła Jana Herburta z Fulsztyna. Anna ze Zborowskich Borkowa Gostyńska żyła jeszcze w 1588 r. ${ }^{53}$ Dodajmy również, że podana przez Ewę Dubas-Urwanowicz informacja, że „Zygmunt Kurzbach ojciec zmarł 31 XII 1579 r.” (s. 55) mogłaby sugerować, że jest to data śmierci pierwszego męża Anny ze Zborowskich. W rzeczywistości tego właśnie dnia zmarł (zginął $\mathrm{w}$ wyniku wybuchu prochu) jej jedyny syn $z$ małżeństwa $z$ Janem Kurzbachem.

Trzecia córką Marcina Zborowskiego i Anny z Góry Konarskiej była Katarzyna, która około 1546 r. wyszła za mąż za Hieronima Ossolińskiego h. Topór (zm. 1575/1576), późniejszego kasztelana sandomierskiego. Miała $z$ nim siedmiu synów - Marcina (zm. 1580), Zbigniewa (zm. 1623), wojewodę sandomierskiego, Jana (zm. ok. 1576), Hieronima (zm. 1580/1582), Andrzeja (zm. 1616) oraz Piotra i Mikołaja, zmarłych w 1598 r. Jedyna córka Hieronima i Katarzyny - Zofia poślubiła kasztelana przemyskiego Stanisława Drohojowskiego (zm. 1583). Czwarta córka kasztelana krakowskiego Marcina Zborowskiego - Barbara w 1546 r. została żona Stanisława Mateusza Stadnickiego (zm. 1563). W małżeństwie tym urodziła sześciu synów oraz trzy (Autorka podaje, że dwie) córki. Synami Barbary ze Zborowskich Stadnickiej byli: Stanisław (zm. 1610), zwany Diabłem łańcuckim, Marcin (zm. 1628), kasztelan sanocki, Mikołaj (zm. 1580), Jan (zm. 1620), Samuel (zm. p. 1592) i Andrzej Piotr (zm. 1608). Zdaniem Ewy Dubas-Urwanowicz córkami Stanisława Mateusza Stadnickiego i Barbary ze Zborowskich były: Katarzyna, żona Krzysztofa Włodka $z$ Piekar, oraz Elżbieta, żona sędziego sanockiego Wojciecha Humnickiego. Dodajmy w tym miejscu, że trzecią córką Stanisława Mateusza i Barbary ze Zborowskich była Anna Stadnicka, żona Andrzeja Grudzińskiego ${ }^{54}$. Sprostowania wymaga też informacja, że Marianna Stadnicka, córka kasztelana sanockiego Marcina, została żoną wojewody krakowskiego Mikołaja Zebrzydowskiego (s. 57, 778). W istocie bowiem Marianna poślubiła nie zmarłego w 1620 r. przywódcę rokoszu sandomierskiego,

${ }^{53}$ Por. BK PAN, TD, Poznań, Inskrypcje, XVI wiek, Część 2, 7514 (Nr. 894), 1558; 8865 (Nr. 931), 1578; 5122 (Nr. 949), 1588.

${ }^{54}$ Już w 1578 r. Anna Stadnicka występowała jako wdowa po Andrzeju Grudzińskim. Żyła jeszcze w 1595 r. Por. BK PAN, TD, GiZ, Poznań, Inskrypcje, XVI wiek, Część 2, 8656 (Nr. 931), 1578; GiZ, Nakło, 2567 (Nr. 162), 1595. 
ale jego wnuka - Michała (zm. 1667), który również u schyłku życia został wojewoda krakowskim.

Piątą córką Marcina Zborowskiego i Anny z Góry Konarskiej była Elżbieta (Halszka). Przed 1559 r. wyszła ona za mąż za Jana Amora Tarnowskiego h. Leliwa (zm. 1571/1574). Miała $z$ nim synów Marcina (zm. 1595/1596) i Jana Gratusa (zm. 1626), kasztelana żarnowskiego, oraz córkę Katarzynę, wspomnianą w 1576 r. Być może córką Jana Amora Tarnowskiego i Halszki Zborowskiej była również Zofia, żona nieznanego $z$ imienia Michowskiego. Drugim mężem Elżbiety Zborowskiej został we wrześniu 1574 r. (wbrew woli niemal wszystkich jej braci, poza banita Samuelem) Andrzej Dudycz, eks-biskup Pięciu Kościołów. W małżeństwie z Dudyczem Halszka Zborowska miała synów: Maksymiliana, Aleksandra, Daniela i Hieronima oraz córki Reginę i Magdalenę (Autorka nie podaje jej imienia). Regina Dudyczówna wyszła za wybitnego działacza ariańskiego, Hieronima Moskorzewskiego. Jej siostra - Magdalena poślubiła, zapewne w 1593 r., Jana Polickiego ${ }^{55}$. Andrzej Dudycz zmarł 24 lutego 1589 r. Elżbieta ze Zborowskich pożegnała się natomiast $z$ tym światem w roku 1601. We fragmencie ksiażki Ewy Dubas-Urwanowicz dotyczącym potomków Elżbiety ze Zborowa dwie kwestie wymagają sprostowania. Żona jej najstarszego syna - Marcina Tarnowskiego była nie Elżbieta Szalówna (s. 58), ale Elżbieta Szalowska. Wnuk Halszki ze Zborowskich (syn Jana Gratusa) - Jan Rafał Tarnowski był natomiast starostą żarnowieckim, a nie żarnowskim, jak podała Autorka.

Krystyna Zborowska była szóstą, najmłodszą córką kasztelana krakowskiego Marcina i Anny z Konarskich. Jej mężem został około 1562 r. Jan Chodkiewicz (zm. 1579), z czasem starosta żmudzki, marszałek ziemski, kasztelan wileński i administrator Inflant. Dziećmi Jana i Krystyny byli: Hieronim (zm. 1576), Aleksander (zm. 1626), wojewoda trocki, Jan Karol (1570/1571-1621), wojewoda wileński i hetman wielki litewski, oraz Zofia (zm. 1596), żona Krzysztofa Dorohostajskiego (zm. 1615), marszałka wielkiego litewskiego, Anna, żona kniazia Joachima Koreckiego (zm. 1613), Elżbieta, poślubiona najpierw kniaziowi Janowi Żylińskiemu, a następnie kasztelanowi nowogródzkiemu Samuelowi Wołłowiczowi i wreszcie najmłodsza $z$ rodzeństwa - Aleksandra, która wyszła za kniazia Adama Wiśniowieckiego (zm. 1621). W tej części swojego wywodu Autorka popełniła kilka błędów merytorycznych. Starający się o rękę

${ }^{55}$ Por. BK PAN, GiZ, Wschowa, Część 1, 797 (Nr. 12), 1593. 
Krystyny Zborowskiej w 1562 r. Jakub Basilikos Heraklides nie był hospodarem wołoskim (s. 59), tylko mołdawskim. Matką dzieci wojewody trockiego Aleksandra Chodkiewicza była nie Katarzyna $z$ Korniaktów (s. 61, 731, 733), która zmarła bezpotomnie, ale jego pierwsza żona - Eufemia $z$ Sienieńskich. Prokop Sieniawski (zm. 1627), mąż jedynej córki Aleksandra Chodkiewicza - Anny Eufrozyny, nie był chorażym nadwornym (s. 61), lecz chorążym wielkim koronnym. Mąż Krystyny Zborowskiej - Jan Chodkiewicz nigdy nie był hetmanem wielkim litewskim (s. 62). Absolutnie niezgodne $z$ prawda jest stwierdzenie, że „dobra litewskich wnuków Marcina Zborowskiego weszły więc jak widać do domów Sieniawskich, Sapiehów, Dorohostajskich, Koreckich, Wiśniowieckich i Wołłowiczów" (s. 62). Wszystkie dobra po wojewodzie trockim Aleksandrze Chodkiewiczu odziedziczyli bowiem Sieniawscy. Dobra zaś jego brata, wojewody wileńskiego Jana Karola (z Bychowem, Lachowiczami i Kretynga), przeszły w całości na Sapiehów. Ewidentnym brakiem jest $\mathrm{w}$ tej partii książki nieumieszczenie jakiejkolwiek wzmianki o dzieciach Joachima Koreckiego i Anny Chodkiewiczówny. Warto w tym miejscu przypomnieć, że synami tej pary, a zatem wnukami Krystyny ze Zborowskich Chodkiewiczowej byli sławni kniaziowie Samuel i Karol (Jan Karol) Koreccy. Pierwszy z nich, znany zagończyk kresowy, wzięty do niewoli po klęsce cecorskiej, został zamordowany przez Turków w Stambule w 1622 r. Drugi z braci, znany ze swojego oddania dla Zygmunta III, cieszacy się mirem wśród Kozaków, w 1623 r. zasiadł w senacie jako kasztelan wołyński. Zmarł w 1633 r. Ożeniony z Anną Potocką h. Pilawa, był ojcem ostatniego męskiego potomka kniaziów na Korcu - Samuela Karola (1621-1651).

Sporo zastrzeżeń budzi fragment pracy traktujący o pozycji ekonomicznej rodu Zborowskich. Co prawda, Autorka zastrzega się, że przedstawia jedynie zarys problemu, ale nie usprawiedliwia to bynajmniej szeregu popełnionych tu pomyłek. Nieprawda jest, że córki kasztelana krakowskiego wnosiły swoim mężom posagi w wysokości 8000 złotych oraz dobra nieruchome (s. 65). Zofia, Anna i Barbara Zborowskie $z$ cała pewnością otrzymały po 3000 złotych posagu. Być może Elżbieta (Halszka) dostała nieco więcej (4000 złotych), która to suma, oprawiona w podwójnej wysokości (posag i wiano) na dobrach mężowskich, dała W. Dworzaczkowi asumpt do błędnego stwierdzenia, że wniosła ona Janowi Amorowi Tarnowskiemu 8000 złotych. Nie jest również możliwe, aby Marcin 
Zborowski uposażał córki dobrami ziemskimi. Co prawda, Zdzisław Pietrzyk, autor biogramu Stanisława Mateusza Stadnickiego w Polskim słowniku biograficznym, podaje, że wraz z ręką Barbary Zborowskiej otrzymał on od teścia kilka wsi w województwie krakowskim, ale jest to stwierdzenie co najmniej watpliwe. Pomijając przytaczane przez Ewę Dubas-Urwanowicz informacje o pojedynczych wioskach, które stanowiły dziedziczną własność Zborowskich, zajmijmy się jedynie większymi kompleksami majątkowymi. Autorka podaje, że „do Samuela Zborowskiego należały prawem dziedzicznym Złoczów i Mikulińce” (s. 66). Twierdzi także, że „w rękach Zborowskich te dobra [mowa o Złoczowie - Z.A.], nabyte od Sieniawskich, pozostawały prawdopodobnie do lat osiemdziesiątych/ dziewięćdziesiątych, kiedy trafiły na krótko do Górków. W 1592 r. wykupił je Marek Sobieski. Potomkowie Zborowskich utracili więc Złoczów, natomiast Mikulińce posiadał przez całe życie Aleksander Zborowski, syn Samuela" (s. 67). W innym miejscu możemy przeczytać, że „Mikulińce w Tarnopolskiem należały najpierw do Jordanów, potem do Zborowskich. Prawdopodobnie dostały się w ręce rodu Zborowskich wraz z ręką Barbary albo Zofii Jordanówny. Pierwsza była żona Andrzeja Zborowskiego, druga - Samuela. Jest bardzo prawdopodobne, iż uzyskała je po ojcu Zofia $z$ Jordanów Zborowska, żona Samuela" (s. 68). Nie bardzo rozumiem, jak pogodzić tę ostatnią konstatację $z$ podana wcześniej informacja, że Marcin Zborowski, protoplasta rodu, był w posiadaniu zamku w Mikulińcach (s. 66)?

A jak sprawa własności Złoczowa i Mikuliniec wyglądała w rzeczywistości? Rozległa, ale słabo zagospodarowana włość złoczowska należała do Górków. W 1562 r. Łukasz Górka, wówczas wojewoda łęczycki, pożyczył od Marcina Zborowskiego, wówczas wojewody poznańskiego, 70 tys. złotych i w tej sumie zastawił mu Złoczów $z$ przyległościami ${ }^{56}$. Zborowscy władali więc majątkiem złoczowskim jako zastawnicy, ale pod względem formalnoprawnym należał on w dalszym ciagu do Górków. Przyznać trzeba, że w okresie swoich rządów Zborowscy poczynili w Złoczowie szereg inwestycji. Ściagali też osadników i zakładali nowe wsie i miasteczka. W 1592 r. zmarł jednak ostatni z Górków - wojewoda poznański Stanisław i cały ogromny spadek po nim trafił w ręce jego siostrzeńców - braci Czarn-

56 Por. BK PAN, TD, GiZ, Poznań, Inskrypcje, XVI wiek, Część 2, 1639 (Nr. 904), 1562. 
kowskich. W 1597 r. dworzanin królewski Stanisław Czarnkowski odstapił bratu Piotrowi swoje prawa do przypadłego mu w spadku po wuju klucza złoczowskiego pod warunkiem, że ten ostatni wykupi te dobra $z$ rąk potomków Samuela Zborowskiego ${ }^{57}$. W roku 1598 Andrzej Czarnkowski, kasztelan rogoziński, oraz Piotr Czarnkowski, podkomorzy poznański, wykupili Złoczów od Aleksandra i Samuela Zborowskich i natychmiast odstapili ten majątek wojewodzie lubelskiemu Markowi Sobieskiemu. Warto zaznaczyć, że dobra złoczowskie obejmowały wówczas miasto i zamek Złoczów, świeżo założone miasteczka Zborów, Andropol i Rytwiany oraz 69 wsi $^{58}$. Jeśli chodzi o Mikulińce, to była to posiadłość Sieniawskich. Dobra przeszły we władanie Jordanów wraz z ręką Anny Sieniawskiej żony, Spytka Wawrzyńca, kasztelana krakowskiego. Jordanowa pozostała właścicielka Mikuliniec aż do śmierci, która nastąpiła latem 1597 r. Samuel Zborowski i jego żona Zofia Jordanówna byli więc tylko użytkownikami tej majętności. Dopiero 8 sierpnia 1597 r., kiedy podzielono spadek po kasztelanowej krakowskiej, klucz mikuliniecki przeszedł na własność dzieci banity Samuela. Dobra te obejmowały wówczas miasto i zamek Mikulińce nad Seretem oraz wsie Ładyczyn, Łuczkę, Skomorochy i Kozówkę. Do majętności mikulinieckiej zaliczano również miasto Zawałów nad Gniłą Lipą oraz wsie Zastawce, Serednie i Zaturzyn. Warto tu także dodać, że na schedę spadkobierców Zofii z Jordanów Zborowskiej przypadły również wsie Mogilany, Głogoczów, Włoson i Zawada w województwie krakowskim. Do działu tego weszło też leżące w tym samym województwie miasteczko Dukla $z$ pięcioma przyległymi wsiami. Dobra te pozostawały jednak w zastawie spadkobierców Oktawiana Guczego, od których Zborowscy mieli je dopiero wykupić59.

Kilkuwioskowy kompleks majątkowy stanowiły wieś Pleszów oraz części wsi Kowala, Zębocin, Żerków, Grębocin i Mniszów w województwie krakowskim. Dobra te, dawniej należące do Szydłowieckich, kupił kasztelan krakowski Marcin Zborowski od Karola Krzysztofa ks. ziębickiego. Już jednak sześć lat po śmierci kasztelana krakowskiego jego wnuk Piotr, syn Marcina, kasztelana krzy-

57 Por. BK PAN, TD, GiZ, Poznań, Rezygnacje, XVI wiek, 14984 (Nr. 1402), 1597.

58 Por. BK PAN, TD, GiZ, Poznań, Rezygnacje, XVI wiek, 15259 (Nr. 1402), 1598.

59 Por. ANK, CCI nr 161, s. 967-968. Dodajmy w tym miejscu, że włość mogilańska przypadła w udziale Annie ze Zborowskich Mortęskiej. Dopiero po jej śmierci, w 1602 r. Ludwik Mortęski, działając w imieniu małoletnich córek, odprzedał ten majątek Aleksandrowi Zborowskiemu. 
wińskiego, sfinalizował transakcję sprzedaży tej majętności ${ }^{60}$. Dodajmy jednak, że dobra te młody Zborowski sprzedał za 10 tys. złotych nie jakiemuś Marcinowi Liczce (s. 68), tylko prepozytowi tarnowskiemu Marcinowi z Ryglic Łyczce h. Sulima. Autorka wspomina również o kluczu korzkiewskim w województwie krakowskim. Dobra te, składające się z zamku (nie miasta, jak na s. 68) Korzkiew oraz wsi Grębienice, Biały Kościół, Maszyce, Januszowice i połowy Pękowic, nabył w 1545 r. Piotr Zborowski, późniejszy kasztelan sandomierski. Po jego bezpotomnej śmierci Korzkiew przeszła na jego brata Marcina, z czasem kasztelana krakowskiego. Później klucz korzkiewski stanowił własność jednego $z$ synów Marcina - Mikołaja, starosty szydłowskiego i rumborskiego. Ten z kolei w 1568 r. pożyczył od Szymona Ługowskiego, prepozyta miechowskiego, sumę 8500 złotych, oddając mu w zastaw Korzkiew z przyległościami ${ }^{61}$. W rezultacie już w lipcu 1572 r. Piotr, Jan, Andrzej, Samuel i Krzysztof Zborowscy, opiekunowie Krzysztofa i Piotra, nieletnich synów nieżyjącego już Mikołaja, byli zmuszeni sprzedać temuż Ługowskiemu dobra korzkiewskie za 18 tys. złotych ${ }^{62}$. $Z$ tekstu recenzowanej ksiaż̇ki dowiadujemy się również, że do Zborowskich należały (w różnych okresach) następujące dobra: w województwie sandomierskim część wsi Czyżów, wsie Nazów, Kikowa, Zborów i część wsi „Boleyów”; w województwie krakowskim wsie Bolów $^{63}$, Marchocice, połowa Kloniowa, Śledziejowice ${ }^{64}$, Bogucice, Brzegi i Czarnochowice ${ }^{65}$; w województwie ruskim zaś klucze Zabło-

60 Transakcja ta została przeprowadzona i zarejestrowana w księgach grodu nowokorczyńskiego już w sierpniu 1571 r. Dnia 15 III 1574 r. została natomiast potwierdzona i wpisana w Krakowie do akt Metryki Koronnej. Por. AGAD, MK 111, k. 126-132.

${ }^{61}$ Por. AGAD, MK 101, k. 197-200v.

62 Potwierdzenie dokonanej 7 VII 1572 r. sprzedaży Korzkwi nastapiło w Krakowie 29 III 1574 r. Por. AGAD, MK 111, k. 161-168. Autorka błędnie podaje (s. 68), że Szymon Ługowski nabył dobra korzkiewskie dopiero 7 VII 1582 r.

${ }^{63} \mathrm{Na}$ s. 296 omawianej pracy znalazło się stwierdzenie, że 1 V 1574 r. Krzysztof Zborowski zrzekł się praw do wsi Bolów, Bolowic i Nadzów w ziemi przemyskiej (!), oddanych w zastaw za sumę 8 tys. złotych. Dodajmy, że w przywołanym przez Autorkę dokumencie pada stwierdzenie, że wsie te leżały w powiecie proszowskim. Podano tu również, że dobra te zostały oddane na dwa lata Erazmowi Czeczotce. Por. AGAD, MK 113, k. 96v-100v. W późniejszym okresie Bolów i Nadzów stanowiły własność Prospera Prowany.

${ }^{64} \mathrm{~W}$ dniu 1 V 1574 r. Samuel Zborowski obciażył tę wieś długiem w wysokości 4400 florenów zaciagniętym od Prospera Prowany. Por. AGAD, MK 113, k. 92-96.

${ }^{65}$ Dnia 5 VI 1588 r. wsie Brzegi i Czarnochowice, skonfiskowane Krzysztofowi Zborowskiemu, nadał król Zygmunt III w dziedzictwo Krzysztofowi Jordanowi. Por. AGAD, MK 135, k. 132-132v. 
tów i Okno ${ }^{66}$, Dębowiec oraz Cieszybiesy (s. 65-69). Przyznać trzeba, że daje to dość nikłe wyobrażenie o rozległości dóbr ziemskich familii, uznanej przez Ewę Dubas-Urwanowicz za najpotężniejsza rodzinę możnowładczą w Koronie w drugiej połowie XVI w.

Warto więc może podać w tym miejscu kilka dodatkowych informacji. W pierwszej kolejności wspomnieć trzeba, że w rękach rodu Zborowskich od końca XIV do końca XVI stulecia pozostawał klucz zborowski w powiecie wiślickim. W jego skład wchodziło stare gniazdo rodu - wieś Zborów z zamkiem oraz wsie Janów, Solec, Żuków, Mały Piasek, Gadawa, Sukowice, Włosnowice, Kijków, Lubusz, Lubuska Wola vel Brzozówka, Bierzychowice, Bossowice i Śreniawa vel Wólka. Krótko przed 1598 r. poważnie zadłużony kasztelan biecki Andrzej Zborowski sprzedał te dobra kasztelanowi sandomierskiemu Stanisławowi Tarnowskiemu ${ }^{67}$. Od 1549 r. w rękach Zborowskich znajdowała się także włość, którą można określić mianem zalidowskiej w województwie sandomierskim. Kupił ją w styczniu podczas sejmu piotrkowskiego od wojewody ruskiego Piotra Firleja ówczesny kasztelan kaliski Marcin Zborowski, a transakcja obejmowała wsie Ujazd, Ujazdek, Boduszów, Mydłów, Grzybów, Gryzikamień, Wygiełzów, Łopatno, Łopacienko, Dziewiątle, Zwola, Wieprzka i miasto Zalidów (ostatecznie jego lokacja nie doszła do skutku) ${ }^{68}$. Nie wiemy niestety, jak długo władali Zborowscy nabytymi od Firleja dobrami. W XVII w. należały już do Ligęzów. Warto jednak odnotować, że w styczniu 1616 r. ich właścicielem został wnuk Marcina Zborowskiego - Zbigniew Ossoliński, wojewoda sandomierski, który właśnie wtedy kupił te dobra od podstolego sandomierskiego Sebastiana Ligęzy. Własnością Zborowskich było również miasto Oleśnica, które stanowiło centrum kolejnego klucza dóbr w województwie sandomierskim. Dobra oleśnickie zostały jednak zastawione Krzysztofowi Lanckorońskiemu

${ }^{66}$ Należy w tym miejscu wyjaśnić, że Zabłotów i Okno były królewszczyznami. Dzierżawa obejmowała miasto Zabłotów z wsiami Zadubrowie, Ciołkowce, Okno i Tarnawa. W dniu 20 I 1588 r. w Krakowie Zygmunt III nadał Zabłotów z przyległościami Mikołajowi Oleśnickiemu h. Dębno, późniejszemu wojewodzie lubelskiemu. Dobra te wróciły do dyspozycji monarchy po śmierci Piotra Zborowskiego (najpewniej syna Mikołaja, kasztelana krzywińskiego). Por. AGAD, MK 134, k. 49-50.

${ }^{67}$ Por. W. Dworzaczek, Hetman Jan Tarnowski. $Z$ dziejów możnowładztwa małopolskiego, Warszawa 1985, s. 420, 423.

${ }^{68}$ Por. AGAD, MK 76, k. 255; J. Pielas, Oleśniccy herbu Dębno w XVI-XVII wieku. Studium z dziejów zamożnej szlachty doby nowożytnej, Kielce 2007, s. 124; P. Ju siak, Majątki rodziny Firlejów z Dąbrowicy $w$ pierwszej połowie XVI wieku, Lublin 2011, s. 124. 
i nie wróciły już do potomków kasztelana krakowskiego Marcina ${ }^{69}$. Wiemy również nieco więcej o dobrach Cieszybiesy. Ich skład podano bowiem w dokumencie donacji tego majatku (w rzeczywistości była to zapewne sprzedaż wyderkafowa) dokonanej w kwietniu 1574 r. przez Andrzeja i Krzysztofa Zborowskich na rzecz Melchiora Paniowskiego. W skład włości, położonej w powiecie halickim, wchodziło wówczas miasto Cieszybiesy oraz wsie Staresioło, Hanuszowce, Pobereże, Jastrzębiec, Sielce, Kijowce i Bohorodczany ${ }^{70}$. W późniejszym okresie majątek ten musiał wrócić do Zborowskich, gdyż skonfiskowane Krzysztofowi Zborowskiemu „za zbrodnie obrazy majestatu i zdrady kraju" miasto Cieszybiesy z przyległościami nadał król Zygmunt III w kwietniu 1588 r. na dziedziczną własność Jakubowi Potockiemu h. Pilawa, późniejszemu wojewodzie bracławskiemu $^{71}$. Dodajmy również, że Potoccy zmienili nazwę świeżo pozyskanego miasteczka, nazywając je Jezupolem.

Jest sprawa oczywistą, że Zborowscy posiadali również znaczne dobra w Wielkopolsce. Nie wchodzac w zbyt daleko idące szczegóły, powiedzmy tylko, że Mikołaj Zborowski, kasztelan krzywiński, oraz jego synowie byli dziedzicami na Kobiernie. W chwili ich sprzedaży w 1579 r. dobra te obejmowały wsie osiadłe: Kobierno, Dabrowa, Tomice Wielkie, Bijatki, Duszyna vel Zborówka oraz wsie puste: Tomice Małe, Brzoza, Zagorzupie, Sarzowy, Duszna Górka i Świnkowa ${ }^{72}$. Żona Mikołaja, Urszula $z$ Rozdrażewskich, była natomiast właścicielka części miasta Września oraz wsi Zawodzia, Chocicy, Zasułtowa i części Psar. W 1557 r. dobra te sprzedała jednak biskupowi krakowskiemu Andrzejowi Zebrzydowskiemu ${ }^{73}$. Do Urszuli z Rozdrażewa Zborowskiej należały również wsie Dzielcze, Wrożewy i połowa Bodzienna ${ }^{74}$. Jan Zborowski, kasztelan gnieźnieński, był natomiast właścicielem części miasta Iwanowice, przedmieścia Niemiecka Wieś oraz wsi Korzekwino. W 1570 r. sprzedał jednak ten majątek Dobrogostowi Potworowskiemu, sędziemu ziemskiemu kaliskiemu, za 10 tys. złotych ${ }^{75}$. W tym samym roku

${ }^{69}$ Por. AGAD, MK 135, k. 173-174.

${ }^{70}$ Por. AGAD, MK 113, k. 36-38. Dodajmy, że donacja na rzecz Paniowskiego obejmowała również wieś Marchocice i połowę Kloniowa w województwie krakowskim.

${ }^{71}$ Por. AGAD, MK 135, k. 18v-21v.

72 Por. BK PAN, TD, GiZ, Kalisz, Rezygnacje, XVI wiek, 723 (Nr. 5), 1579.

73 Por. BK PAN, TD, GiZ, Poznań, Rezygnacje, XVI wiek, 8367 (Nr. 1396), 1557.

74 Por. BK PAN, TD, GiZ, Kalisz, Inskrypcje, XVI wiek, 2177 (Nr. 23), 1558.

75 Por. BK PAN, TD, GiZ, Kalisz, Rezygnacje, XVI wiek, 4583 (Nr. 3), 1570. 
Jan Zborowski został odnotowany jako właściciel wsi Gostyczyna ${ }^{76}$. Zborowski dzierżawił również należące do klasztoru bożogrobców w Miechowie wsie Grodzisko, Rokutów, Jankowo i Sierzchowo w powiecie kaliskim. W 1566 r. dokonał (za zgoda braci) wymiany dóbr $z$ bożogrobcami. Oddał im dziedziczna wieś Głuchów w powiecie proszowskim (dopłacajacc 8000 złotych), a w zamian otrzymał pełne prawo własności do wszystkich dzierżawionych wcześniej od miechowskiego klasztoru wsi w powiecie kaliskim ${ }^{77}$. Najpoważniejszym nabytkiem Jana Zborowskiego były jednak dobra pleszewskie. Kupił je już po ślubie $z$ Elżbietą ks. Prońską. Pewne wyobrażenie o rozległości tych dóbr daje transakcja ich sprzedaży. Majętność pleszewska zbył bowiem w 1638 r. na rzecz Aleksandra z Otoka Zaleskiego wnuk Jana Zborowskiego, Jan Piotr Opaliński, podstoli koronny. Dobra te obejmowały wówczas miasto Pleszew i wsie Wola Pleszewska, Baranów, Baranówko, Piekarzów, Zawidowice i Małynie. W ich skład zaliczono również, pozyskane przez kasztelana gnieźnieńskiego od miechowskich bożogrobców, wsie Grodzisko i Rokutów ${ }^{78}$. Dodajmy wreszcie na zakończenie, że trzecia żona Jana - Katarzyna $z$ Konarskich wniosła mu połowę miasta Zduny oraz wsie Baszków, Bestwin, Ruda i Dzierżanowo w powiecie pyzdrskim ${ }^{79}$.

Nie należy również zapominać o tym, że latyfundium Zborowskich zostało powiększone w drugiej połowie XVI w. przez majatki wniesione do tego domu przez żony synów Marcina, kasztelana krakowskiego. O dobrach, które dziedziczyły żony Marcina, kasztelana krzywińskiego, Jana, kasztelana gnieźnieńskiego, i banity Samuela wspomniałem wcześniej. W tym miejscu warto przypomnieć, że Piotr Zborowski, wojewoda krakowski, objął w imieniu żony połowę spadku po swoim teściu, kasztelanie wojnickim Mikołaju Myszkowskim. Wiemy na pewno, że Piotr i Barbara Zborowscy byli właścicielami połowy dóbr Spytkowice w powiecie oświęcimskim i zatorskim. Jeszcze większy majątek przypadł natomiast w udziale żonie Andrzeja Zborowskiego, Barbarze z Jordanów. W 1597 r., kiedy dokonano podziału dóbr ziemskich po jej rodzicach, otrzymała ona bowiem połowę klucza melsztyńskiego (druga połowę dostała jej siostra Magdalena, wdowa po kasztelanie sandomierskim Sta-

\footnotetext{
76 Por. BK PAN, TD, GiZ, Kalisz, Inskrypcje, XVI wiek, 4002 (Nr. 36), 1570.

77 Por. BK PAN, TD, GiZ, Kalisz, Rezygnacje, XVI wiek, 413 (Nr. 2), 1566.

78 Por. BK PAN, TD, Zap. Tryb. Piotrk., 579 (Nr. 29), 1638.

79 Por. BK PAN, TD, GiZ, Wschowa, Część 2, 533 (Nr. 205), 1614.
} 
nisławie z Sulejowa Sobku) ${ }^{80}$. W 1629 r. w rękach jedynego żyjącego wówczas syna Barbary $z$ Jordanów Zborowskiej - Andrzeja, kasztelana oświęcimskiego, znajdowała się połowa zamku Melsztyn, połowa miasta Zakliczyn oraz 18 wsi całych i trzy części wsi ${ }^{81}$. Nie zapominajmy również o tym, że już w okresie obniżenia się rangi rodu tenże Andrzej Zborowski, $z$ oczywistych względów używający tytułu „hrabia na Melsztynie”, nabył w latach 1624-1625 znaczne dobra w województwie kijowskim. Były to włość trypolska $z$ miastem Trypol oraz miasto Iwnica $z$ wsiami Hrabolew, Kleszczówka, Siażątka i Stare Sioło. Warto dodać, że o ile Trypol już w 1633 r. został przez nich sprzedany Maksymilianowi Brzozowskiemu, to Iwnicę utrzymali Zborowscy w swoich rękach aż do wybuchu powstania Chmielnickiego ${ }^{82}$. Wspomnijmy wreszcie na koniec, że Marcin Zborowski podjął próbę nabycia dóbr rytwiańskich od Hieronima Łaskiego. Pieniądze na zakup „rodowego gniazda Zborowskich” pożyczył jednak od Andrzeja Tęczyńskiego (zm. 1561), $z$ czasem kasztelana krakowskiego, któremu oddał w zastaw Rytwiany z przyległościami. Sprawa skończyła się tym, że Tęczyńscy nie dali się spłacić i utrzymali klucz rytwiański w swoich rękach aż do wygaśnięcia rodu w 1637 r. Niepowodzeniem zakończyła się również próba nabycia przez Marcina Zborowskiego klucza pilickiego. Ostatecznie bowiem miasto Pilice $z$ kilkunastoma wsiami kupił dla swojego brata Wojciecha, który został w przyszłości kasztelanem oświęcimskim, biskup krakowski Filip Padniewski.

Jak więc widzimy, kasztelan krakowski Marcin Zborowski zgromadził w swoim ręku bardzo znaczny majątek i położył podwaliny pod potęgę swojego rodu. Konieczność podziału schedy po Marcinie między jego synów i wnuków (synów Marcina) znacznie osłabiła jednak pozycję ekonomiczna rodu. Utrzymanie dotychczasowej pozycji rodziny wymagało bowiem dostępu do łaski królewskiej i udziału w eksploatacji królewszczyzn. Tego zaś w dłuższej perspektywie czasowej zabrakło. Ewa Dubas-Urwanowicz w sposób niezwykle szczegółowy przedstawiła w omawianej książce udział przedstawicieli rodu Zborowskich w życiu politycznym państwa polskiego (od 1569 r. polsko-litewskiego) na przestrzeni XVI stulecia. Nie sposób

80 Por. ANK, CCI nr 161, s. 966-967.

${ }^{81}$ Por. Rejestr poborowy województwa krakowskiego z roku 1629, oprac. W. Domin, J. Kolasa, E. Trzyna, S. Żyga, red. S. Inglot, Wrocław 1956, s. 210, 212, $217-$ 220, 224, 232, 249, 266-267, 275-276.

${ }^{82}$ Por. H. Litwin, op. cit., s. 180. 
nie zgodzić się z jej spojrzeniem na omawiane zagadnienia. Warto jednak wyeksponować w tym miejscu niektóre konkluzje Autorki. Jest bowiem sprawą oczywista, że poczatki kariery rodu Zborowskich należy powiązać $z$ protekcją, jaką roztaczali nad braćmi Marcinem i Piotrem ich wujowie, Krzysztof i Mikołaj Szydłowieccy. Po śmierci obu Szydłowieckich Zborowscy związali się $z$ reformatorskim ruchem średnioszlacheckim, widzac w tym droge do swoich przyszłych karier. Zwłaszcza Marcin Zborowski okazał się bardzo zręcznym graczem politycznym, który lawirując między szlachtą a monarcha, potrafił zgromadzić w swoim ręku ogromny majatek i sięgnąć po najwyższy w hierarchii senatorów świeckich urząd kasztelana krakowskiego. Jego pozycja w państwie była na tyle silna, że potrafił przekazać w ręce synów wszystkie zgromadzone przez siebie królewszczyzny. Na szczególne podkreślenie zasługuje to, że po śmierci Marcina jego synowie, kierowani przez stojącego na czele rodu Piotra, wojewodę sandomierskiego, a następnie krakowskiego, dwukrotnie potrafili doprowadzić do wyboru popieranych przez siebie kandydatów do tronu polskiego. W obie elekcje zaangażowali jednak ogromne środki finansowe i doprowadzili do znacznego zadłużenia posiadanych przez siebie dóbr. Panowanie Henryka Walezego było jednak zbyt krótkie, aby Zborowscy mogli otrzymać choć częściowy zwrot kosztów jego elekcji. Jeszcze większy zawód spotkał braci ze strony Stefana Batorego, w którego wybór ponownie zaangażowali ogromne środki. Nowy władca Rzeczypospolitej nie poczuwał się bowiem do żadnej wdzięczności wobec nich, a swoim głównym doradca i współpracownikiem uczynił Jana Zamoyskiego. Konflikt $z$ królem i jego faworytem doprowadził Zborowskich do prawdziwej katastrofy politycznej (ścięcie Samuela, infamia Krzysztofa). Ostatecznie pogrążyła ich jednak dopiero klęska ich kandydata do korony w czasie trzeciego bezkrólewia. Porażka arcyksięcia Maksymiliana oznaczała koniec znaczenia Zborowskich na scenie politycznej. Upadek polityczny zbiegł się w czasie $z$ postępującym zubożeniem rodziny. Zadłużeni synowie i wnukowie Marcina Zborowskiego wyprzedawali kolejno odziedziczone po nim majętności. Na pograniczu bogatej szlachty i magnaterii utrzymał się jedynie Jan, kasztelan gnieźnieński, oraz jego bratankowie - synowie Andrzeja i Samuela, którzy dzięki swoim matkom otrzymali część spadku po kasztelanie krakowskim Spytku Wawrzyńcu Jordanie. 
Odpowiadajac na zawarte $\mathrm{w}$ tytule omawianej pracy pytanie, kim byli Zborowscy: mężami stanu, awanturnikami czy zdrajcami?, Ewa Dubas-Urwanowicz napisała: „Na pewno nie byli mężami stanu. Działali na polu publicznym i wojskowym przede wszystkim ze względu na karierę osobistą bądź chęć wzmocnienia pozycji całego domu. Popierali panujących w ich programach politycznych wówczas, gdy mogło im to przynieść korzyść. Kasztelan krakowski Marcin i jego trzej synowie: Andrzej, Krzysztof i Samuel byli awanturnikami. Ich ekstremalne ekscesy, napady na drodze, zabójstwa, działania pod wpływem emocji wykluczały ich $z$ grona osób uważanych za poważnych polityków. Marcin dzięki współpracy z królem od końca lat pięćdziesiątych przeżył ewolucję. Zaczął autentycznie, choć nie bezinteresownie, włączać się w życie publiczne, z pozytywnym skutkiem dla państwa. Podobną fazę pozytywnej działalności publicznej widzimy w przebiegu kariery osobistej Piotra w czasie jego misji dyplomatycznej do Turcji i w okresie pierwszego interregnum. Bardzo pozytywnie można ocenić militarna działalność Jana Zborowskiego. Trudno go jednak nazwać mężem stanu. Być może zabrakło mu zdolności. Czarną legendę rodu budowali jednak przede wszystkim Krzysztof i Samuel. Nie ma wątpliwości, iż zarówno jeden, jak i drugi działali przeciwko interesom państwa polsko-litewskiego. Jeden, intrygujac w czasie pobytu na dworzec cesarskim przeciwko uznanemu przez ogół obywateli, koronowanemu królowi, Stefanowi Batoremu. Drugi $-z$ pobudek osobistych prowokując wojnę $z$ Turcją, która miała przynieść korzyści Cesarstwu, a nie Rzeczypospolitej" (s. 698-699). Nie sposób nie zgodzić się w całości z przedstawionym tu wywodem.

$\mathrm{Na}$ tym można by w zasadzie zakończyć nasze rozważania. Nie sposób jednak nie odnieść się do zbyt dużej mimo wszystko liczby błędów, pomyłek i nieścisłości występujących w tekście recenzowanej pracy. Większość $z$ nich składam na karb zbyt pośpiesznej, a przez to niedokładnej redakcji i korekty. Niemniej jednak wszystkie one obciążają tak wydawnictwo, jak i samą Autorkę. Zacznijmy może od kwestii związanych $z$ wyjaśnieniem związków rodzinnych między postaciami pojawiającymi się na kartach omawianej książki. Zofia z Tęczyńskich Zborowska nie była bynajmniej siostrą Katarzyny z Tęczyńskich Radziwiłłowej (s. 69), tylko jej dalszą krewną. Matką Hieronima Szafrańca, drugiego męża Zofii Zborowskiej, nie była Anna z Chodcza (s. 89-90, 765), ale Zuzanna Buczacka. Szydłowieccy roztaczajacy opiekę nad braćmi Marcinem i Piotrem Zborow- 
skimi nie byli ich szwagrami (s. 91), tylko wujami. Piotr Kmita nie był powinowatym Jana Tarnowskiego (s. 119), ale bliskim krewnym (był synem dużo starszej, przyrodniej siostry hetmana, czyli jego siostrzeńcem). Podobnie kniaź Dymitr Sanguszko, określony przez Autorkę jako powinowaty kniazia Konstantego Wasyla Ostrogskiego (s. 159), w rzeczywistości był jego krewnym (jego babka Maria ks. Ostrogska była rodzona siostra Konstantego, ojca Konstantego Wasyla). Również Stanisława $z$ Sulejowa Sobka i Marcina Zborowskiego łączyły więzy nie powinowactwa (s. 178), ale pokrewieństwa (Sobek był wnukiem Anny Szydłowieckiej, rodzonej siostry Elżbiety, matki Zborowskiego). Podobna uwagę należy odnieść do Górków. Ostatni przedstawiciele tej rodziny - Łukasz, Andrzej i Stanisław nie byli powinowatymi Zborowskich (s. 361, 536, 694), tylko ich krewniakami (babka Górków - Zofia ze Zborowskich była rodzona siostra Marcina, kasztelana krakowskiego, i Piotra, kasztelana sandomierskiego). Zbigniew Ossoliński nie był też bynajmniej szwagrem (s. 535), ale siostrzeńcem Krzysztofa Zborowskiego. Tę samą uwagę odnieść można do braci Zbigniewa Ossolińskiego i Stadnickich, synów Stanisława Mateusza (s. 694). Jest także sprawą oczywistą, że dla Stanisława Stadnickiego, zwanego Diabłem łańcuckim, Andrzej i Krzysztof Zborowscy byli wujami, a nie kuzynami (s. 673). Ten sam stopień pokrewieństwa łączył ich $z$ Marcinem Borkiem Gostyńskim, nazwanym powinowatym Zborowskich na s. 673. Inny siostrzeniec braci Zborowskich - syn kasztelana santockiego Wojciecha Ostroroga Lwowskiego miał na imię Marcin, a nie Jan, jak dwukrotnie na s. 361. Żeby zaś sprawę bardziej zagmatwać, na s. 645 pada stwierdzenie, że Marcin Ostroróg Lwowski był wujem braci Zborowskich.

Zwróćmy też uwagę na to, że biskup kujawski Hieronim Rozdrażewski nie mógł spokrewnić się $z$ domem Zborowskich przez małżeństwo Marcina, kasztelana krzywińskiego, z Urszulą Rozdrażewską (s. 536). Przesadą jest też nazywanie go bliskim powinowatym Zborowskich (s. 657). Z żoną kasztelana krzywińskiego łączyło go bowiem dość odległe pokrewieństwo (ich dziadkowie byli rodzonymi braćmi). W tym miejscu nasuwa się zreszta pytanie, czy za powinowatych Zborowskich uznać można wszystkich reprezentantów rodziny, $z$ której wzięli sobie małżonkę, lub też, do której weszła jedna $z$ ich córek. Niezbyt uzasadnione wydaje się np. używanie określania „powinowaty” w odniesieniu do Stanisława Szafrańca (s. 361, 540), który był stryjecznym bratankiem Hieronima, drugiego 
męża Zofii Zborowskiej. Dokładnie to samo zastrzeżenie można też sformułować w przypadku Spytka Wawrzyńca Jordana (s. 394, 428, 489), stryjecznego bratanka kasztelana krakowskiego Spytka Wawrzyńca, z którego córkami ożenili się Andrzej i Samuel ${ }^{83}$. Warto także przypomnieć, że synowie Mikołaja Radziwiłła Czarnego nie byli braćmi stryjecznymi synów Mikołaja Radziwiłła Rudego (s. 487). Uwaga ta dotyczy rzecz jasna również Mikołaja Radziwiłła „Sierotki” (syna Czarnego) i Krzysztofa Radziwiłła „Pioruna” (syna Rudego) (s. 641). Aż dwa błędy merytoryczne zawiera stwierdzenie, że w imieniu Katarzyny z Maciejowskich, wdowy po Andrzeju Wapowskim, mowę do króla Henryka wygłosił jej brat, wojewoda lubelski Stanisław Maciejowski (s. 290). W rzeczywistości wojewoda lubelskim był bowiem wówczas Mikołaj Maciejowski, który nie był bratem Katarzyny. Na s. 292, informujacc o jego śmierci w marcu 1574 r., Autorka nazywa go już poprawnie Mikołajem i określa bliższym prawdy mianem kuzyna żony Wapowskiego (Mikołaj był bratem stryjecznym ojca Katarzyny, Stanisława, kasztelana sandomierskiego). Dodajmy wreszcie, że pierwsza żona Hieronima Szafrańca, starosty chęcińskiego - Regina, nie nosiła nazwiska „z ksiażąt litewskich” (s. 157). Tak nazywał się jedynie jej starszy brat Jan, legitymizowany przez papieża Juliusza II. Ona sama nosiła nazwisko po matce - Ochstat. Współcześni nazywali ja jednak zwykle Regina, córka króla Zygmunta I. Wśród uchybień związanych $z$ kwestiami genealogicznymi wymienić też trzeba uporczywe nazywanie banity Samuela najmłodszym synem kasztelana krakowskiego Marcina (s. 301, 382, 385, 388, 405, 416, 442, 453, 500, 514).

Do rzędu ewidentnych pomyłek należy zaliczyć stwierdzenie, że Piotr Kmita sprawował urząd wojewody poznańskiego (s. 52). Marcin Ostroróg Lwowski nie był też kasztelanem kamienieckim (s. 395), tylko kamieńskim. Przywołanym na s. 445 podkomorzym wieluńskim był nie Jerzy, ale Piotr Boksa Radoszewski. Andrzej Górka nie piastował nigdy urzędu wojewody poznańskiego (s. 452, 611). W czerwcu roku 1586, ani tym bardziej w roku następnym, nie mógł zresztą piastować żadnych urzędów, gdyż zmarł w już 1583 r. (jako kasztelan międzyrzecki). Wspomnianym tu wojewodą był wówczas jego młodszy brat - Stanisław. Jan Dymitr Solikowski nie był

${ }^{83}$ Ojciec Spytka Wawrzyńca, kasztelana krakowskiego - kasztelan wojnicki Mikołaj był bratem kasztelana bieckiego Jana, dziadka Spytka Wawrzyńca, stolnika krakowskiego i starosty sądeckiego. 
arcybiskupem gnieźnieńskim (s. 472), tylko lwowskim. Stanisław Radzimiński nie mógł piastować urzędu kasztelana czerwińskiego (s. 586) ani też wojewody czerskiego (s. 653), gdyż nie było takich godności w państwie polskim doby nowożytnej. Janusz ks. Ostrogski nie był nigdy kasztelanem wołyńskim (s. 586). W 1587 r. urząd ten pełnił Michał Myszka Warkowski. Podobnie kardynał Jerzy Radziwiłł nigdy nie był biskupem płockim (s. 638), Szymon Szczawiński wojewodą inowrocławskim (s. 587), a Gabriel Hornostaj wojewodą bracławskim (s. 270). Mikołaj Firlej nie mógł być w 1587 r. wojewodą krakowskim, gdyż urząd ten piastował wówczas występujący w tym samym zdaniu Andrzej Tęczyński (s. 616). Jan Dulski łączył podskarbiostwo wielkie koronne $z$ kasztelania, a nie województwem chełmińskim (s. 652). Mikołaj Zborowski był starostą szydłowskim, a nie szydłowieckim, jak na s. 48 i 224, i konsekwentnie w indeksie. Wspomnianym przez Autorkę na s. 602 chorążym sanockim był $z$ pewnościa Stanisław Tarnawski, a nie Tarnowski. Nieprawdziwa jest także informacja, że Piotr Zborowski był w chwili śmierci ojca kasztelanem wojnickim (s. 185). Nominację na ten urząd otrzymał on bowiem dopiero w 1567 r. W przypadku Mikołaja Herburta, który w czasie trzeciego bezkrólewia zastępował Jana Zamoyskiego w dowodzeniu wojskiem na kresach, dobrze byłoby dodać określenie „Dziedziłowski” lub też konsekwentnie nazywać go podkomorzym halickim, bo taki urząd przecież wówczas pełnił (s. 580, 583, 585). Uczestnika poselstwa do Paryża w orszaku kasztelana gnieźnieńskiego - kniazia Iwana Połubińskiego nazwano Prońskim (s. 279). Wspomnianym tu Połubińskim $z$ pewnościa nie był też Iwan, marszałek hospodarski, który zmarł w 1556 r. (s. 758). Lew Sapieha nigdy nie używał imienia Leon (s. 586). Mniszchowie pisali się z Wielkich Kończyc, a nie Kończyc (s. 586). Podobnie Sobkowie pisali się $z$ Sulejowa, czasami $z$ Sułowa, ale nigdy $z$ Sułowic (s. 226). Wspomniany na s. 276 członek orszaku poselskiego Jana Zborowskiego to $z$ pewnością Stanisław Zaremba $z$ Kalinowy, a nie Stanisław Kalinowski Zaremba $z$ Kalinowa (podobnie też na s. 744). W uzupełnieniu dodajmy, że wspomniani na s. 632 kasztelanowie kamieński i lwowski to odpowiednio Marcin Ostroróg Lwowski i Jan Sienieński. Starosta kruszwickim (s. 643) był w roku 1587 Adam Baliński, a starostwo olsztyńskie pozostawało w tym samym czasie (s. 597) w rękach Joachima Ocieskiego. Warto też zauważyć, że żaden $z$ Koniecpolskich nie nosił imienia Janusz (s. 73). 
Całkowicie nieprawdziwe jest stwierdzenie, że Samuel Zborowski rzucił się na Jana Tęczyńskiego z szablą, która (jak można domniemywać) ugodził w głowę próbującego interweniować Andrzeja Wapowskiego (s. 289). Jest bowiem niepodważalnym faktem, że Wapowski otrzymał ciosy czekanem. W opisie całego zajścia brakuje też informacji, że Jan Tęczyński był bliskim powinowatym Samuela jako rodzony brat Zofii, żony nieżyjącego już Mikołaja, starosty szydłowskiego. Użyte zaś przez Autorkę określenie, że Samuela Zborowskiego „oskarżono o zabójstwo Andrzeja Wapowskiego, kasztelana przemyskiego" (s. 289), mogłoby sugerować, że istniały jakiekolwiek wątpliwości co do tego, kto był jego zabójca. Marcin Zborowski, syn kasztelana krakowskiego, nie mógł próbować zrzec się starostwa (s. 225), gdyż żadnego nie posiadał. Złożył wówczas natomiast kasztelanię krzywińską. Jego rezygnacja $z$ urzędu nie została jednak zaakceptowana przez Zygmunta Augusta. Marcin Zborowski nie mógł sprzedać Sobkom Małogoszcza (s. 92), gdyż była to królewszczyzna. Kniaź Ilia Ostrogski nie zachorował dopiero w sierpniu 1539 r. (s. 157). Już w lutym tego roku został bowiem zrzucony $z$ konia przez Zygmunta Augusta na turnieju rycerskim. Doznał wówczas poważnych obrażeń wewnętrznych, które stały się przyczyna jego ciężkiej choroby i śmierci. Nieprawdziwa jest natomiast informacja, że kniaź Dymitr Wiśniowiecki był jednym $z$ konkurentów do ręki Halszki z Ostroga (s. 158). Całkowicie na bakier $z$ geografia historyczna pozostaje stwierdzenie, że Krzysztof Szydłowiecki „na Podlasiu miał Łuków, na Mazowszu - Sochaczew i Gostyń, w Wielkopolsce - starostwo sieradzkie" (s. 94). Nie wchodząc w oczywiste szczegóły, powiedzmy tylko, że o ile starostów i kasztelanów gostynińskich w czasach staropolskich rzeczywiście nazywano "gostyńskimi”, to trzeba pamiętać o tym, że miejscem ich urzędowania było miasto Gostynin w województwie rawskim. Wspomniany na s. 371 dwór Dubno nie leżał bynajmniej na Wołyniu, tylko w powiecie grodzieńskim województwa trockiego (była to część dzierżawy wołpieńskiej). Nieprawdziwa jest podana dwukrotnie (s. 548, 693) informacja, jakoby ta część Węgier, która pozostawała pod panowaniem Habsburgów, wchodziła w skład Cesarstwa. W rzeczywistości bowiem Węgry nigdy nie były uznawane za kraj należący do Rzeszy Niemieckiej. Trudno też trzecią kampanię inflancką Stefana Batorego, w czasie której wojska polsko-litewskie oblegały Psków, określać mianem „wyprawy na Moskwę w 1582 r.” (s. 19). Krzysztof Zborowski nie mógł przybyć na elekcję w 1587 r. 
„Z wojskiem cudzoziemskiego autoramentu” (s. 635), gdyż nazwa ta pojawiła się dopiero po przeprowadzeniu reform wojskowych przez Władysława IV. Dodajmy także, że jednym $z$ francuskich dworzan Henryka Walezego nie był jakiś Albert Retz de Conti (s. 286, 760 - tu jako de Condi), ale pochodzaccy z Florencji Albert de Gondi (1522-1602), pierwszy książę (duc) de Retz, protoplasta znanego, francuskiego rodu arystokratycznego i dziadek słynnego pamiętnikarza - Jana Pawła Franciszka de Gondi kardynała de Retz.

Niezgodne ze stanem faktycznym sa stwierdzenia, że „prymas nominował Maksymiliana II na króla Rzeczypospolitej” (s. 342), że Zygmunt Waza został nominowany „na króla Korony i Wielkiego Księstwa Litewskiego” (s. 640) czy też, że „wybrano go na króla Rzeczypospolitej” (s. 649). Władcom państwa polsko-litewskiego przysługiwał bowiem tytuł królów polskich i tak też byli oni tytułowani. Uczestnikiem elekcji Stefana Batorego oraz sejmiku lubelskiego w listopadzie 1584 r. z cała pewnościa był Piotr Zborowski, syn Marcina, który był wówczas dorosłym mężczyzną, a nie, jak podaje Autorka (s. 341, 516), Piotr Zborowski, syn Mikołaja (w 1576 r. był on kilkuletnim, a 1584 r. kilkunastoletnim chłopcem). Kompletnie chybione jest stwierdzenie, że uwięzienie przez Krzysztofa Zborowskiego zbiegłego $z$ Mołdawii w 1572 r. hospodara Bogdana IV wynikało $z$ tego, że Zborowski obiecał hospodarowi ręke jednej ze swoich młodszych sióstr (s. 255). Abstrahując już od faktu, że wszystkie siostry Zborowskiego były $\mathrm{w}$ tym czasie zamężne, $z$ przytoczonego poniżej cytatu źródłowego wynika jednoznacznie, że to Bogdan obiecał Zborowskiemu rękę swojej siostry, a później wycofał się $z$ tego zobowiazania. Dodajmy, że w innym miejscu omawianej książki (s. 50-51) sprawa ta została przedstawiona zgodnie ze stanem faktycznym. Nieprawdziwe jest stwierdzenie, że za panowania Stefana Batorego zmarło aż czterech braci Zborowskich (s. 542). W rzeczywistości bowiem zmarli wówczas Piotr i Samuel. Śmierć Marcina i Mikołaja przypadła natomiast jeszcze w dobie rządów Zygmunta Augusta. Jeśli natomiast Krzysztof Zborowski rzeczywiście w 1593 r. przebywał w Odolanowie, to $z$ pewnościa gościł u brata Jana, a nie Andrzeja, jak na s. 687. Mam również poważne watpliwości co do tego, czy Piotr Zborowski, syn Andrzeja, urodzony zapewne przed rokiem 1500, mógł w latach 1545-1546 przebywać na studiach w Królewcu (s. 72). Próbę uzyskania namiestnictwa w Prusach i przejęcia opieki nad zniedołężniałym księciem Albrech- 
tem podjał w 1566 r. Jan Albrecht ks. meklemburski, a nie Jan Albrecht Hohenzollern, jak na s. 199.

Informację o złożeniu przez Walentego Dembińskiego kanclerstwa wielkiego koronnego (s. 364) należałoby uzupełnić o stwierdzenie, że w zamian za kanclerstwo dostał on urząd kasztelana krakowskiego. Podobnie w tym fragmencie pracy, w którym Autorka pisze o próbach pojednania Jana Zamoyskiego $z$ Mikołajem Mieleckim (s. 488), zabrakło informacji o tym, że Mielecki miał do szwagra (obaj byli żonaci $z$ córkami Mikołaja Radziwiłła Czarnego) pretensje o mieszanie się do spraw wojskowych i przyjęcie złożonej przez niego buławy wielkiej koronnej. Przytoczony przez Autorkę cytat źródłowy wyjaśniający przyczynę wrogości Mniszchów i Zborowskich (s. 272) uzupełniłbym o stwierdzenie, że wymieniona tu bogatą wdową była Barbara $z$ Mniszchów, o której rękę, po śmierci jej pierwszego męża, Łukasza Nagórskiego (zm. 1571) starał się bezskutecznie Andrzej Zborowski. Ostatecznie Barbara wyszła za Jana Firleja, marszałka wielkiego koronnego, wojewodę i starostę krakowskiego. Najpewniej z tego właśnie powodu Zborowscy zwrócili się przeciwko Firlejowi i zakwestionowali jego przywództwo w obozie protestanckim w czasie pierwszego bezkrólewia. $Z$ tekstu omawianej pracy nie wynika też jednoznacznie, który $z$ synów Hrehorego (Grzegorza) Chodkiewicza starał się o rękę Elżbiety ks. Prońskiej, która ostatecznie została żona Jana Zborowskiego. Na s. 43 i 227 czytamy bowiem, że była ona zaręczona z Aleksandrem. Na s. 204 znalazła się jednak informacja, że narzeczonym Elżbiety był Andrzej Hrehorowicz. Dodajmy wreszcie na zakończenie, że Andrzej Opaliński, marszałek wielki koronny, wcale nie był stryjem Jana Opalińskiego, kasztelana rogozińskiego (s. 647). W rzeczywistości byli oni bowiem bardzo dalekimi krewnymi.

Staraniem wydawnictwa omawiana książka została zaopatrzona w rozbudowany indeks osobowy, gdzie oprócz nazwiska i imienia danej postaci starano się zamieścić podstawowe informacje o niej. Problem jednak w tym, że do indeksu tego przeniesiono nie tylko wszystkie błędy rzeczowe $z$ tekstu głównego, lecz także popełniono przy okazji szereg kolejnych. Poza tym indeks ten jest wyjątkowo niedokładny i brakuje tu odesłania do wszystkich stron tekstu, na których wystapiła interesująca nas postać. Nie sposób w tym miejscu odnieść się do wszystkich uchybień i niedokładności odnalezionych przeze mnie $\mathrm{w}$ tej części omawianej pracy. Przywołajmy jednak dla potwierdzenia moich zastrzeżeń kilka najbardziej bul- 
wersujących przykładów. Zofii Chodkiewiczównie, domniemanej córce Jana Karola i Zofii z Mieleckich (s. 733), dano za mężów Michała ks. Czartoryskiego (zm. 1582/1583) i Rafała Sieniawskiego (zm. 1592). Mikołaj Dorohostajski nazywany jest konsekwentnie Drohostajskim (s. 733, 735). Janowi Fredrze przypisano urząd kasztelana sandomierskiego (s. 738). Jerzego Fryderyka Hohenzollerna uczyniono księciem pruskim panującym w latach 1577-1604 (s. 743). W haśle poświęconym Katarzynie Medycejskiej Henryka Walezego, który panował we Francji jako Henryk III, nazwano Henrykiem II de Valois (s. 744). Kasztelan przemyski Paweł Korytko został w indeksie Pawłem Korytkowskim (s. 746). Sędka i Sędziwój z Ostroroga zostali odnotowani jako Sędka i Sędziwój z Ostroga (s. 755). Marię z ks. Ostrogskich, babkę Dymitra Sanguszki, wydano za Andrzeja Sanguszkę Koszyrskiego (s. 756), podczas gdy jej mąż o imieniu Andrzej w rzeczywistości pochodził z linii niesuchojesko-łokackiej Sanguszków. Marcin Ostroróg Lwowski został z kolei nie wnukiem Marcina, kasztelana krakowskiego, ale synem jego siostry Zofii (s. 756). Na kartach tej części pracy pojawia się także nieistniejąca w rzeczywistości Elżbieta Prońska ze Zborowskich, córka Jana, kasztelana kaliskiego (s. 758). Stefan Batory i Zygmunt III Waza to $z$ kolei królowie w Rzeczypospolitej (s. 764, 778). Z sobie tylko znanych powodów Autorzy indeksu uznali również, że Zygmunt I Stary był najmłodszym synem Kazimierza Jagiellończyka (s. 778). Podobne przykłady można by oczywiście w sposób dowolny mnożyć. Sporo zastrzeżeń budzi także zamieszczona na końcu pracy tablica genealogiczna rodu Zborowskich. Ponieważ swoje uwagi i zastrzeżenia dotyczace genealogii interesującej nas rodziny zawarłem w poprzednich partiach niniejszego tekstu, poprzestanę na ogólnym stwierdzeniu, że tablica ta wymagałaby również wprowadzenia szeregu, czasami nawet bardzo istotnych poprawek.

$\mathrm{Na}$ zakończenie moich rozważań muszę jednak stwierdzić, że wszystkie przedstawione tutaj uwagi krytyczne nie wpływaja w ostatecznym rozrachunku na wartość merytoryczną omawianej pracy. Niezależnie od wszystkich wskazanych tu usterek, aczkolwiek czasami rzeczywiście irytujących, Ewa Dubas-Urwanowicz w sposób rzetelny, na bardzo szerokim tle rozgrywających się ówcześnie wypadków, przedstawiła udział Zborowskich w życiu politycznym Polski i Rzeczypospolitej. Książkę tę śmiało można więc polecić wszystkim Czytelnikom zainteresowanym dziejami państwa polskiego i polsko litewskiego w XVI stuleciu (ze szczególnym 
uwzględnieniem lat 1572-1587). Na prawdziwa, kompleksową i wieloaspektową monografię rodu Zborowskich zarówno zawodowi historycy, jak i nieprofesjonalni miłośnicy historii będa jednak niestety musieli jeszcze poczekać.

\section{Bibliografia}

\section{ŹRódea ARCHIWALNE}

Archiwum Główne Akt Dawnych w Warszawie [AGAD]

Metryka Koronna [MK] 11, 12, 14, 15, 17, 19, 24, 76, 95, 96, 99, 101, 108, 109, $111,113,134,135,181$.

Archiwum Narodowe w Krakowie [ANK]

Castriensia Cracoviensia Inscriptiones [CCI] nr 122, nr 161.

Biblioteka Kórnicka PAN [BK PAN]

Teki Dworzaczka [TD].

\section{ŹRÓDEA DRUKOWANE}

Akty zjazdów stanów Wielkiego Księstwa Litewskiego, t. I (Okresy bezkrólewi), oprac. H. Lulewicz, Warszawa 2006.

Paprocki B., Herby rycerstwa polskiego, wyd. K.J. Turowski, Kraków 1858.

Rejestr poborowy województwa krakowskiego z roku 1629, oprac. W. Domin, J. Kolasa, E. Trzyna, S. Żyga, red. S. Inglot, Wrocław 1956.

\section{Opracowania}

Anusik Z., Kim była hrabianka Dorota von Helfenstein? Przyczynek do genealogii rodzin Kurzbachów i Helfensteinów w XV wieku, „Przegląd Nauk Historycznych" 2017, R. XVI, nr 2, s. 227-243.

Baczkowski K., Kurozwęcki Mikołaj h. Róża (Poraj), [w:] Polski słownik biograficzny, t. XVI, Wrocław-Warszawa-Kraków 1971, s. 273-274.

Bukowski K., Stosz Zygmunt z Kounic i Olbrachcic, [w:] Polski słownik biograficzny, t. XLIV, Warszawa-Kraków 2006-2007, s. 145-147.

Chłapowski K., Realizacja reform egzekucji dóbr 1563-1665. Sprawa zastawów królewszczyzn małopolskich, Warszawa 1984.

Dubas-Urwanowicz E., Koronne zjazdy szlacheckie w dwóch pierwszych bezkrólewiach po śmierci Zygmunta Augusta, Białystok 1998.

Dubas-Urwanowicz E., O nowy kształt Rzeczypospolitej. Kryzys polityczny w państwie $w$ latach 1576-1586, Warszawa 2013.

Dworzaczek W., Genealogia, t. II (Tablice), Warszawa 1959. 
Dworzaczek W., Hetman Jan Tarnowski. Z dziejów możnowładztwa małopolskiego, Warszawa 1985.

Fałkowski W., Rytwiański Jan (właściwie Jan z Rytwian) h. Jastrzębiec, [w:] Polski słownik biograficzny, t. XXXIII, Wrocław-Warszawa-Kraków 1991-1992, s. $588-592$.

Gąsiorowski, Ostroróg Dobrogost (właściwie Dobrogost z Ostroroga, także z Lwówka, Lwowski), [w:] Polski słownik biograficzny, t. XXIV, Wrocław 1979, s. 499.

Jusiak P., Majatki rodziny Firlejów z Dąbrowicy w pierwszej połowie XVI wieku, Lublin 2011.

Litwin H., Napływ szlachty polskiej na Ukraine 1569-1648, Warszawa 2000.

Lubczyński M., Pielas J., Szydłowiecki Stanisław h. Odroważ, [w:] Polski słownik biograficzny, t. XLIX, Warszawa-Kraków 2013-2014, s. 578-582.

Łoziński W., Prawem i lewem. Obyczaje na Czerwonej Rusi w pierwszej połowie XVII wieku, t. II (Wojny prywatne), wyd. 5, Kraków 1957.

Nowak T., Ścibor z Borysławic, Łubnicy i Rytwian h. Jastrzębiec, [w:] Polski słownik biograficzny, t. L, Warszawa-Kraków 2014-2015, s. 441-442.

Opaliński E., Rodziny wielkosenatorskie w Wielkopolsce, na Kujawach i na Mazowszu za Zygmunta III. Podstawy karier, Warszawa 2007.

Pielas J., Oleśniccy herbu Dębno w XVI-XVII wieku. Studium z dziejów zamożnej szlachty doby nowożytnej, Kielce 2007.

Smoleński M., Melsztyn. O zamku i jego panach, o kościołach i plebanach, $z$ dodatkiem o Domosławicach, Kraków 1888.

Szymczakowa A., Szlachta sieradzka w XV wieku. Magnifici et generosi, Łódź 1998.

Urzędnicy województwa sandomierskiego XVI-XVIII wieku. Spisy, oprac. K. Chłapowski, A. Falniowska-Gradowska, red. A. Gąsiorowski, Kórnik 1993. 